
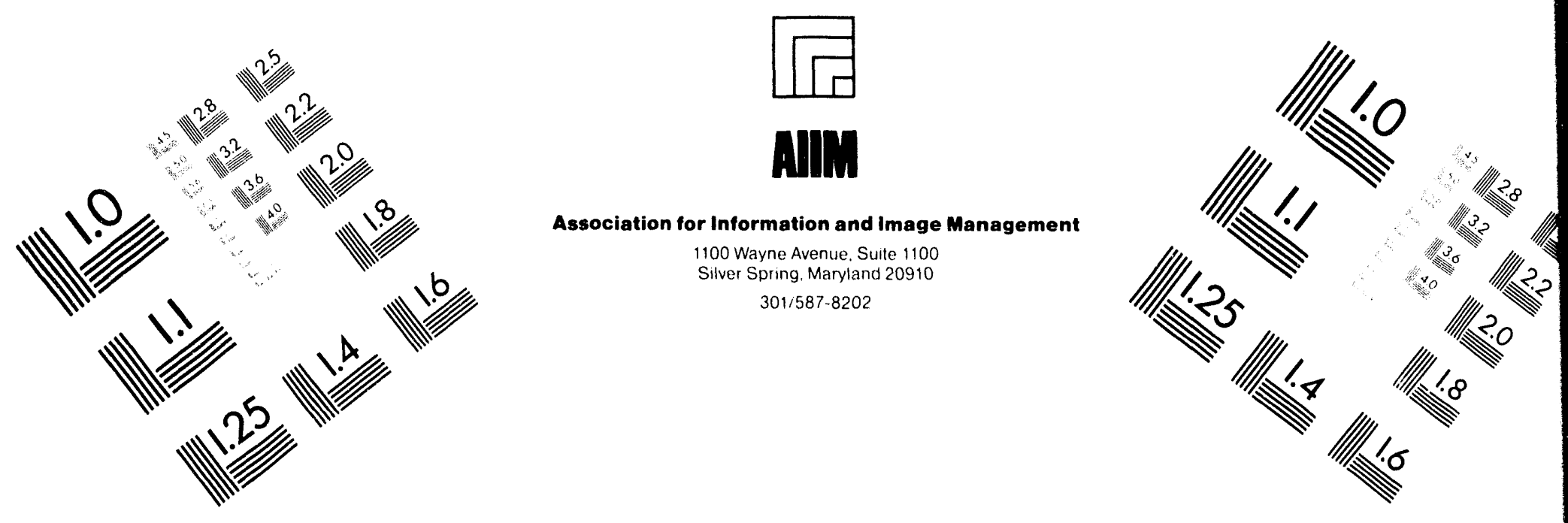

\title{
Centimeter
}

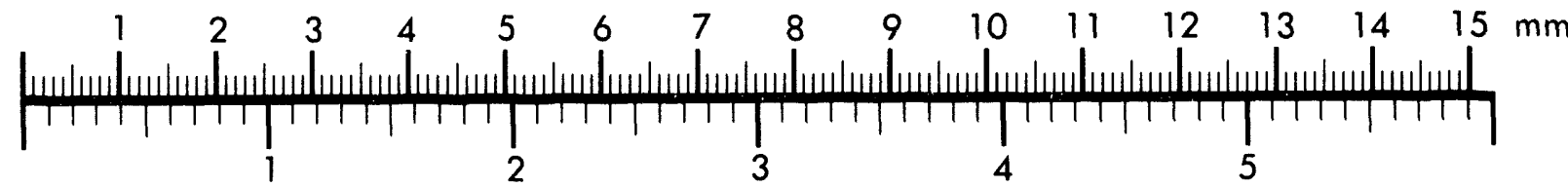

Inches
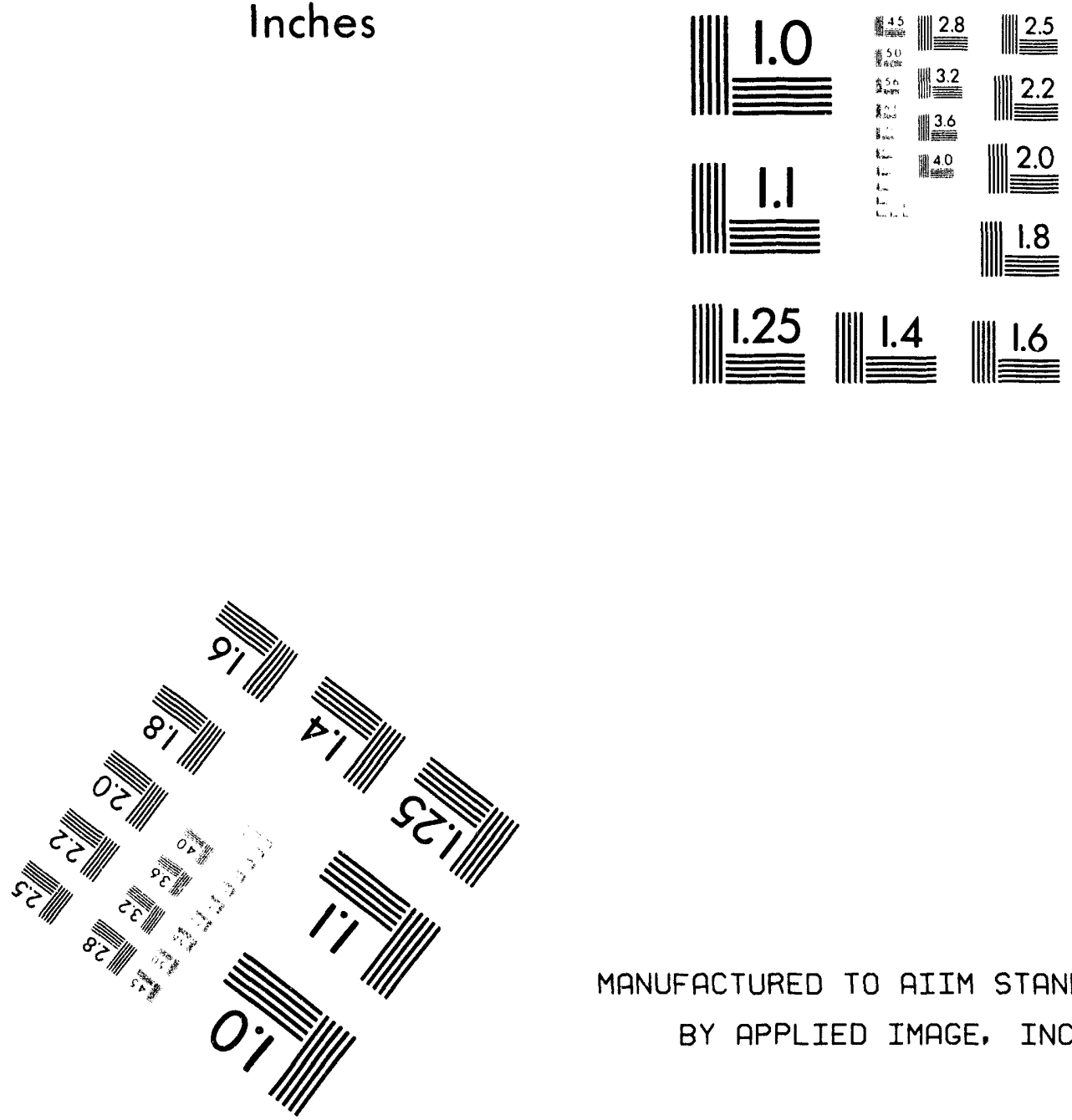

MANUFACTURED TO AIIM STANDARDS

BY APPLIED IMAGE, INC.

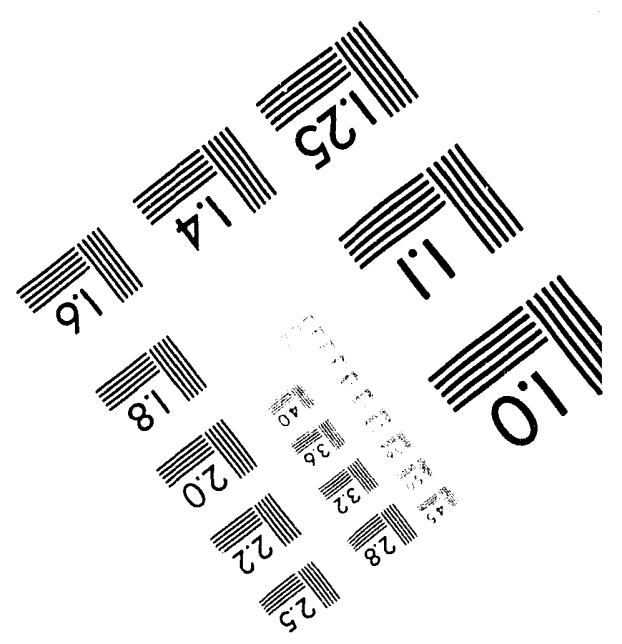



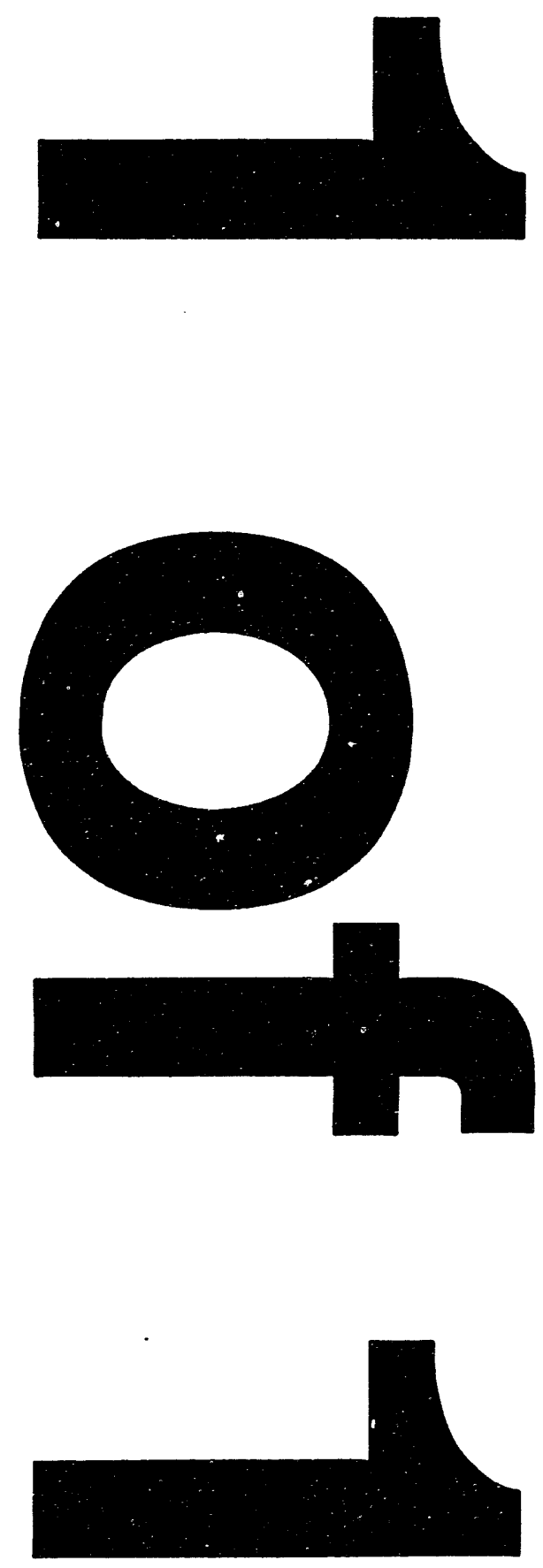
MLM-3789

UC-741

\section{Hazard Classification Assessment for the High Voltage Initiator}

James D. Cogan

Issued: April 19, 1994

\section{MOUND}

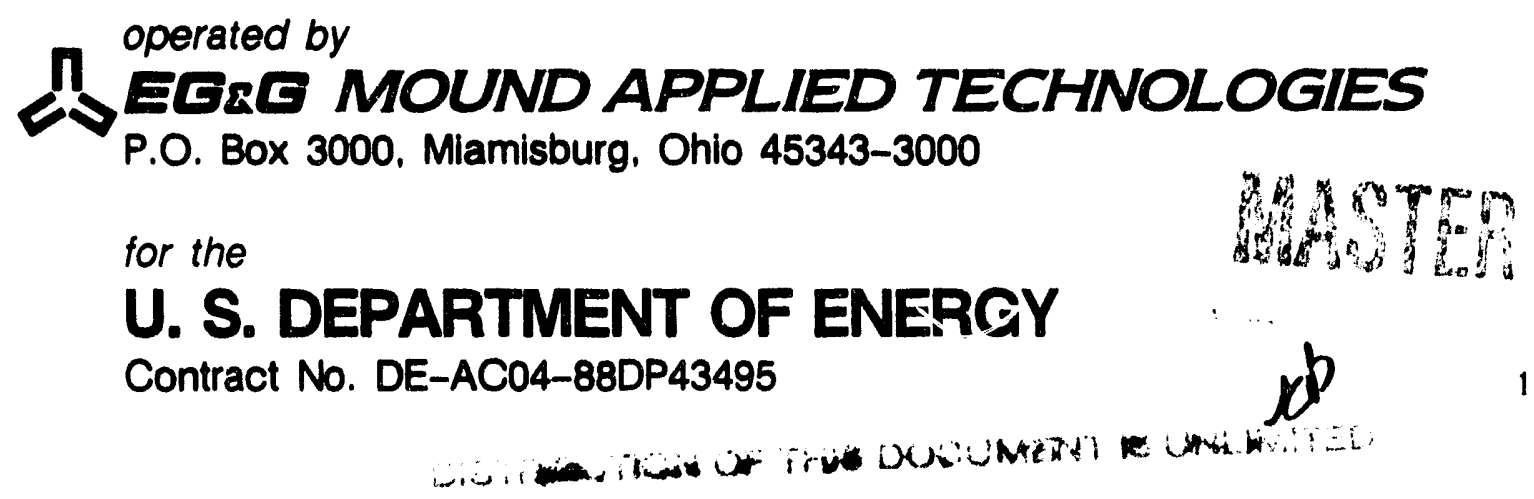




\section{Contents}

page

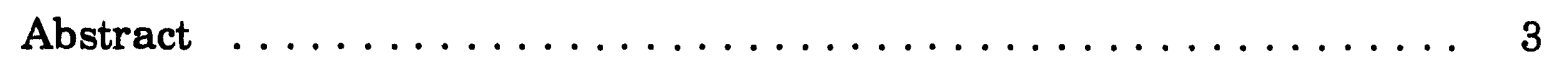

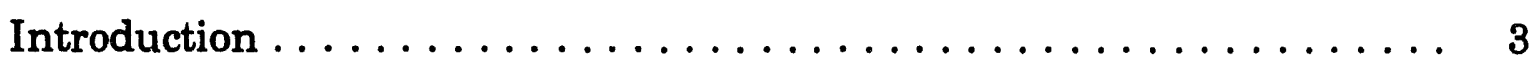

Hazard Classification Testing $\ldots \ldots \ldots \ldots \ldots \ldots \ldots \ldots \ldots$

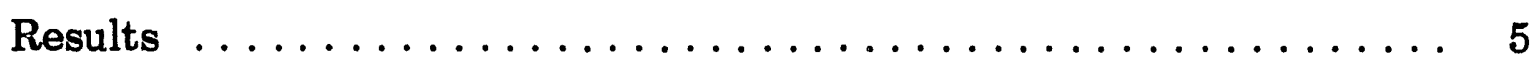

Appendix A, Hazard Classification Documentation $\ldots \ldots \ldots \ldots 17$

Appendix B, Material Safety Data Sheet $\ldots \ldots \ldots \ldots \ldots \ldots \ldots$

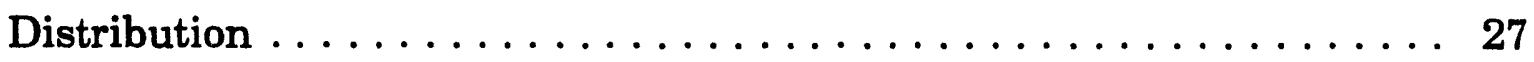




\section{Abstract}

An investigation was conducted to determine whether the High Voltage Initiator (Sandia part number 395710; Navy NAVSEA No. 6237177) could be assigned a Department of Transportation (DOT) hazard classification of "IGNITERS, 1.4G, UN0325" under Code of Federal Regulations, 49 CFR 173.101, when packaged per Mound drawing NXB911442. A hazard classification test was performed, and the test data led to a recommended hazard classification of "IGNITERS, 1.4G, UNO325," based on guidance outlined in DOE Order 1540.2 and 49 CFR 173.56.

\section{Introduction}

The High Voltage Initiator (HVI) was sponsored by a Military Interdepartmental Purchase Request that vias sent to the DOE from the Department of the Navy Strategic Systems Programs. The HVI was designed by Sandia National Laboratories and the SSP 22, Launcher Branch, as a replacement for the EBW/TBI (exploding bridgewire/through bulkhead initiator) currently used in the MK74 Mod O Launch Gas Generator (Reference MIPR 91MP10057). The HVI, made at EG\&G Mound Applied Technologies, contains 0.250 gram of titanium/potassium perchlorate, which is ignited by a hot wire.

The shipping package as described in Mound Certification of Compliance Number 000337 (see Appendix A) was developed to meet the requirements of Code of Federal Regulations, 49 CFR 172.101 (Igniters, 1.4G, UN0325), and International Civil Aviation Organization's (ICAO) Technical Instructions for the Safe Transport of Dangerous Goods by Air (Igniters, 1.4G, UN0325), as well as to protect the HVI during shipping and storage.

A facsimile of the Material Safety Data Sheet is shown in Appendix B. 


\section{Hazard Classification Testing}

The hazard classification test was done on an HVI packaged according to Mound drawing NXB911442. Because final production components were not available, preproduction hardware was used. The package was modified as shown in the figures to allow for a test fire cable to be attached to the initiator assembly.

Figure 1 shows the design of the High Voltage Initiator, Sandia part number 395710, NAVSEA part number 6237177. Figures 2 through 12 show the makeup of the shipping package to be tested. Figure 2 is a picture of the metal drum, AYD770286, with a ring of polyurethane foam and silica gel placed in the bottom for shock support. Figure 3 shows the start of the inner package to be inserted in the metal drum. A styrofoam spacer tray was placed over a long carriage bolt. Figure 4 shows a second blank styrofoam spacer tray placed on the carriage bolt. A slot was cut in this tray to allow for the insertion of the firing cable. Figure 5 shows the shipping tray for the HVI assemblies. The assemblies and the firing cable are not shown.

Figure 6 shows the stack-up with a paper separator placed over the parts tray. Figure 7 shows a styrofoam tray placed over the parts tray on the carriage bolt. The top spacer tray was used to absorb shock from the initiation of the HVI and stop the fragments from hitting the lid.

Figure 8 shows the final stack-up of the inner package with a plywood disc and a lifting strap placed over the spacer tray. Figure 9 shows the HVI and two other assemblies placed in the shipping tray. Figure 10 shows the shipping tray with the firing cable attached. The output from the HVI will be toward the lid.

Figure 11 shows the inner package placed in the metal drum with the firing cable coming out through the humidity indicator hole. A polyurethane foam ring was placed over the inner package to fill the metal drum and allow for 
the addition of silica gel. Figure 12 shows the metal drum ready for testing.

Figures 13 through 22 show the results after the initiation of the High Voltage Initiator. Figure 13 shows that the metal drum was not damaged. Figure 14 shows that no damage was done to the top polyurethane ring. It can be seen in Figure 15 that no damage was done to the top of the spacer tray. Figure 16 shows the resultant damage to the inner package. The side of the top spacer tray was destroyed. Figure 17 shows the inner package with the plywood disc removed. Figure 18 shows the damage to the shipping tray. No propagation was evident. Figure 19 shows that the bottom of the shipping tray was not damaged. The hole in the bottom of the tray was intentionally drilled to allow the passage of the firing cable.

Figure 20 is a top view of the damage to the shipping tray and a bottom view of the top spacer tray. Figure 21 shows the damage to the top spacer tray. Parts of a plastic cap used to protect the output end of the HVI were imbedded in the spacer tray. Figure 22 shows the remains of the HVI assembly. The plastic cap was expanded and the end was blown off. The HVI did not disintegrate; only the welded cover over the $\mathrm{Ti} / \mathrm{KClO}_{4}$ was blown off. All fragments were contained.

\section{Results}

The propagation test results showed that the HVI assembly, when packed according to NXB911442, was nonpropagating and that the packaging contained all the fragments. A recommended hazard classification of "IGNITERS, 1.4G, UN0325" per DOT, ICAO, and DOE regulations is requested. 
a

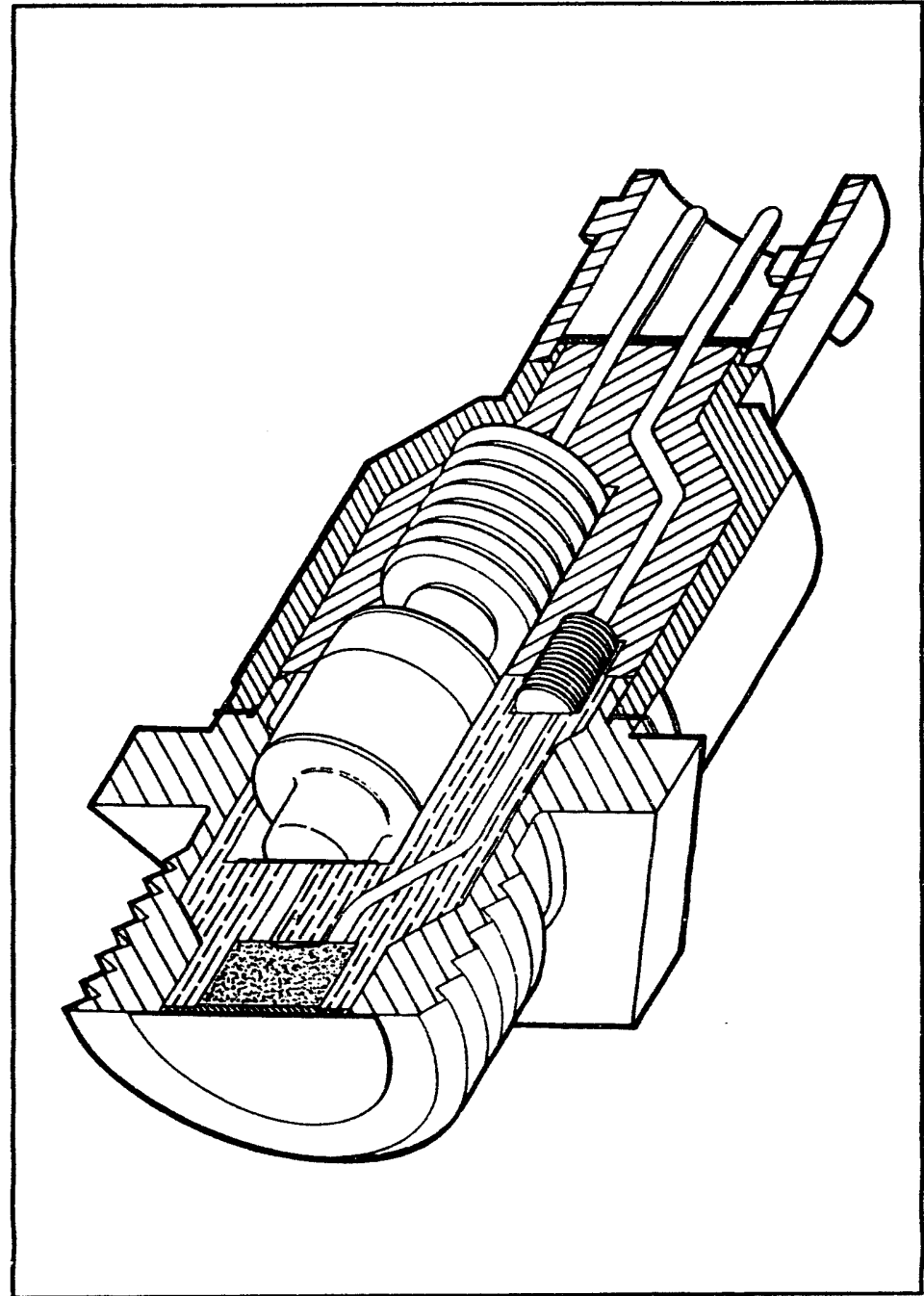

Pigure 1 - High Voltage Initiator, Sandia drawing number 395710.

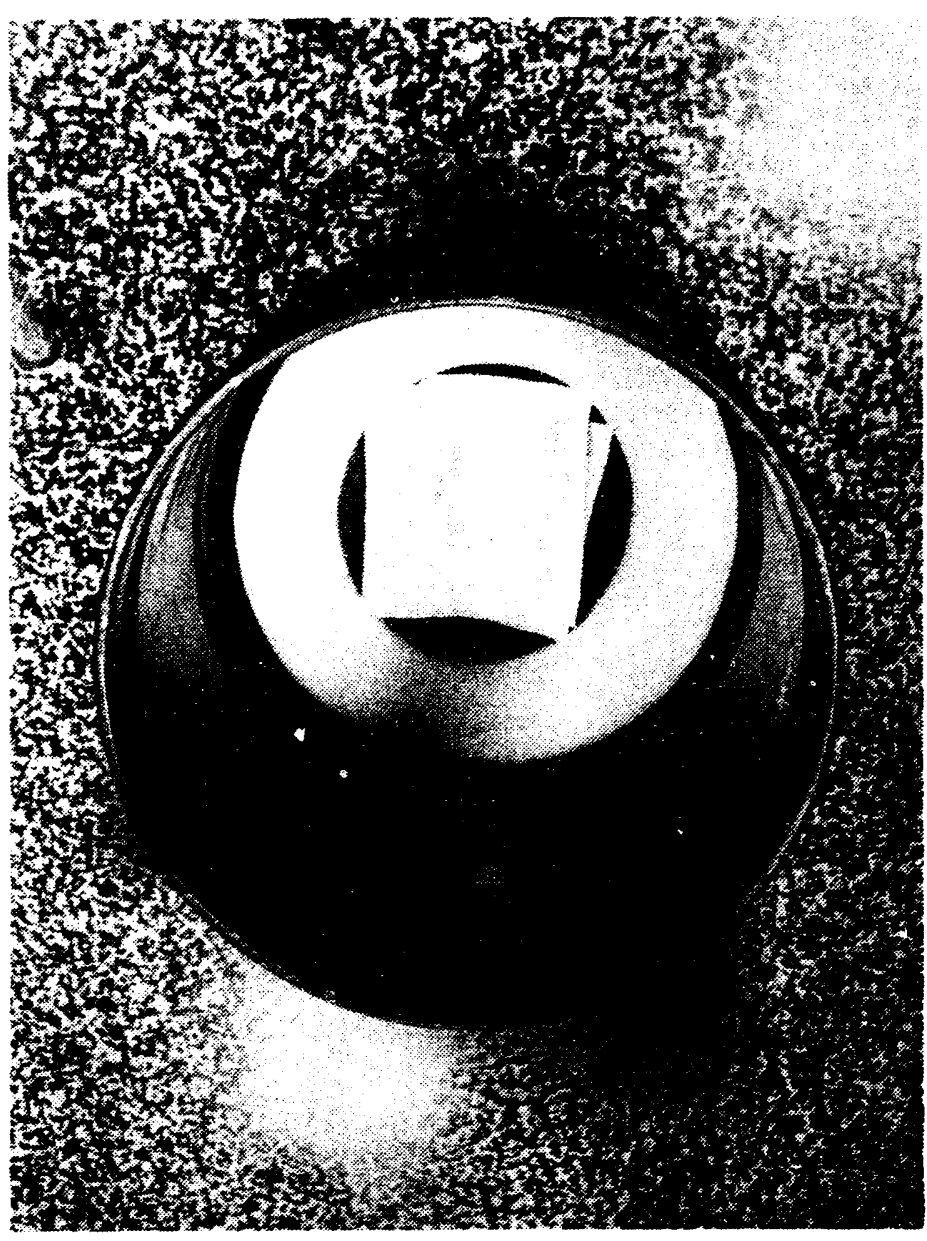

Figure 2 - Metal drum, AYD770286, with polyurethane ring for shock absorption and silica gel. 


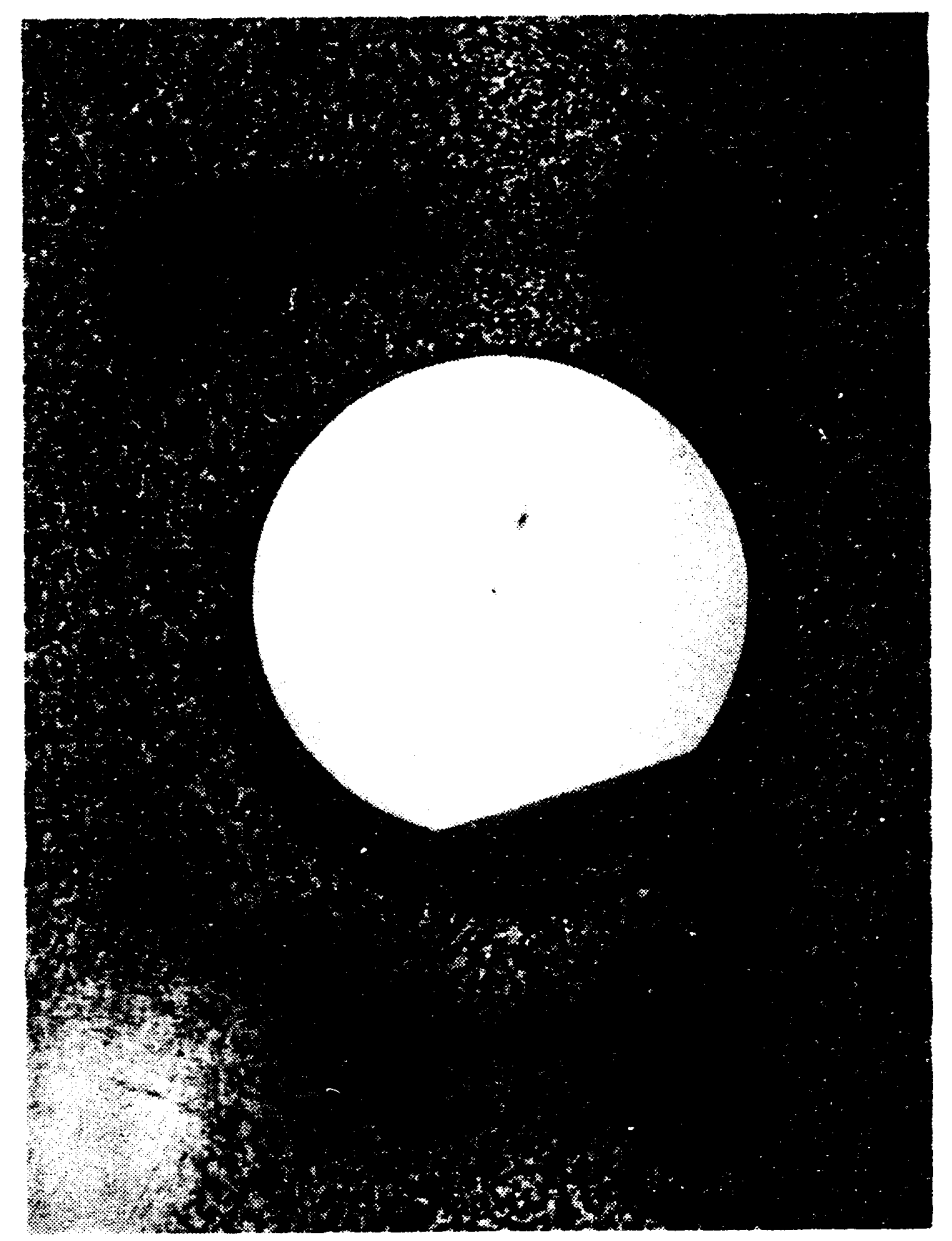

Figure 3 - Start of stack-up of inner package with styrofoam bottom spacer tray placed over carriage bolt.

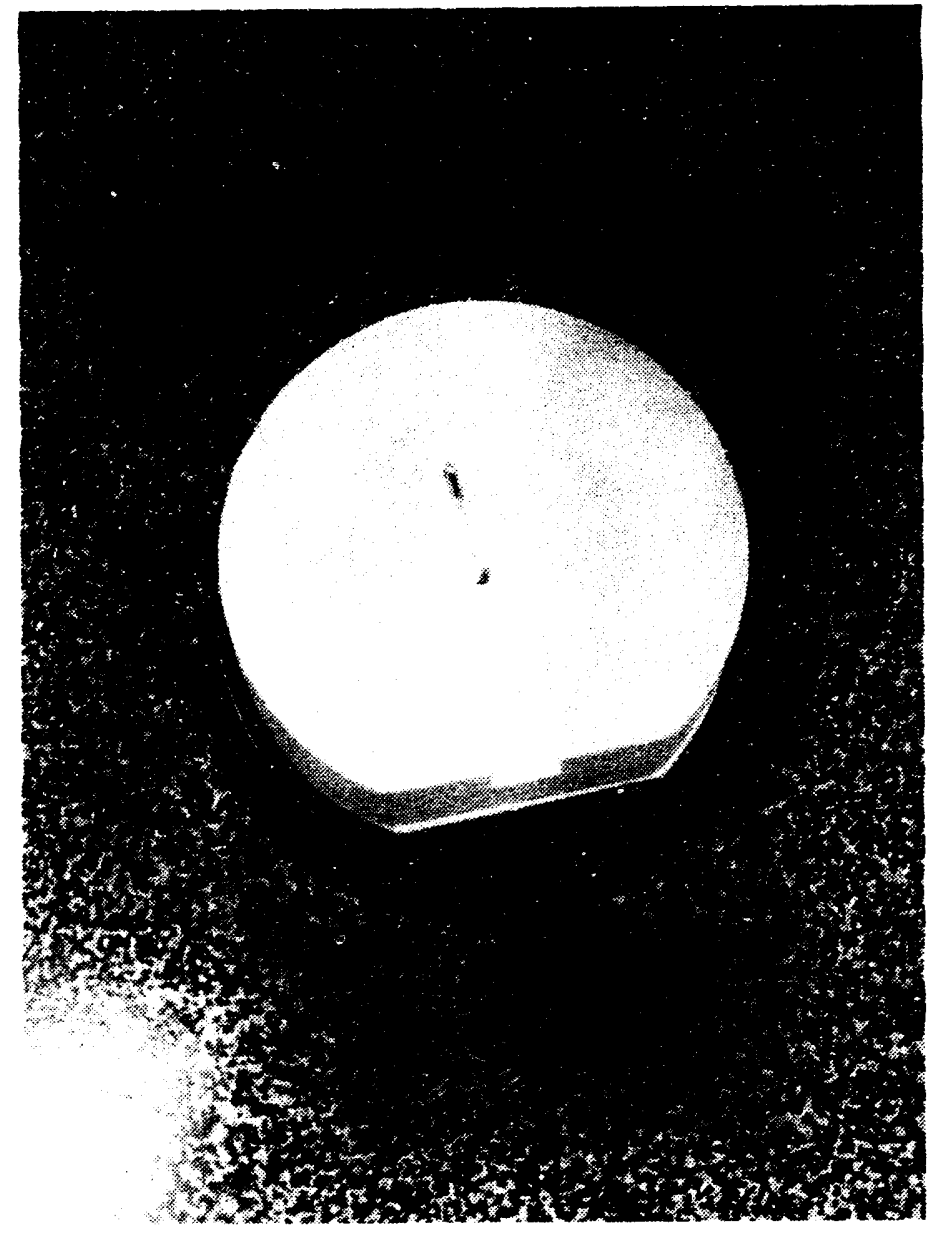

Figure 4 - Another styrofoam spacer tray placed on top of the bottom spacer tray with slot cut for firing cable. 


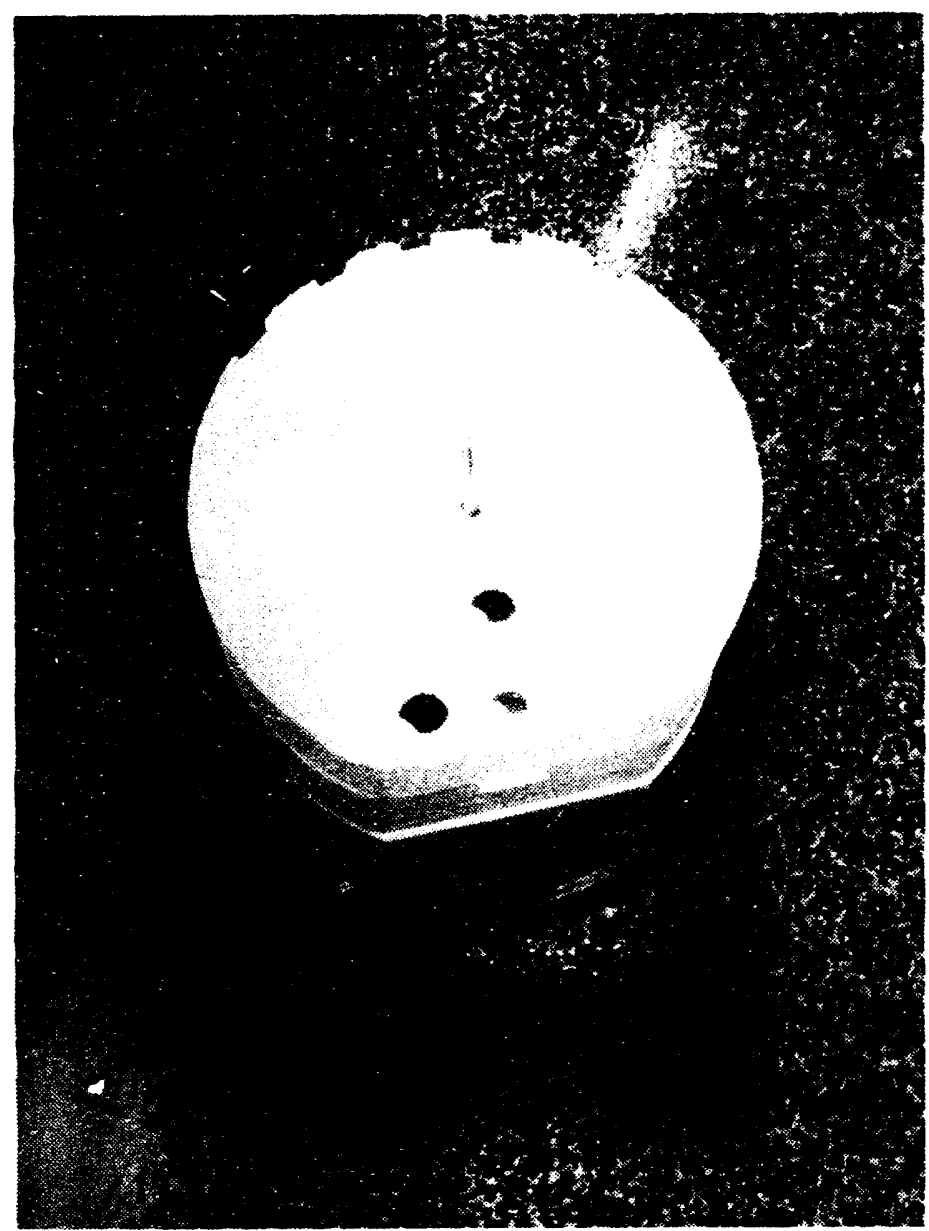

Figure 5 - Styrofoam shipping tray for the HVI placed on top of the spacer tray.

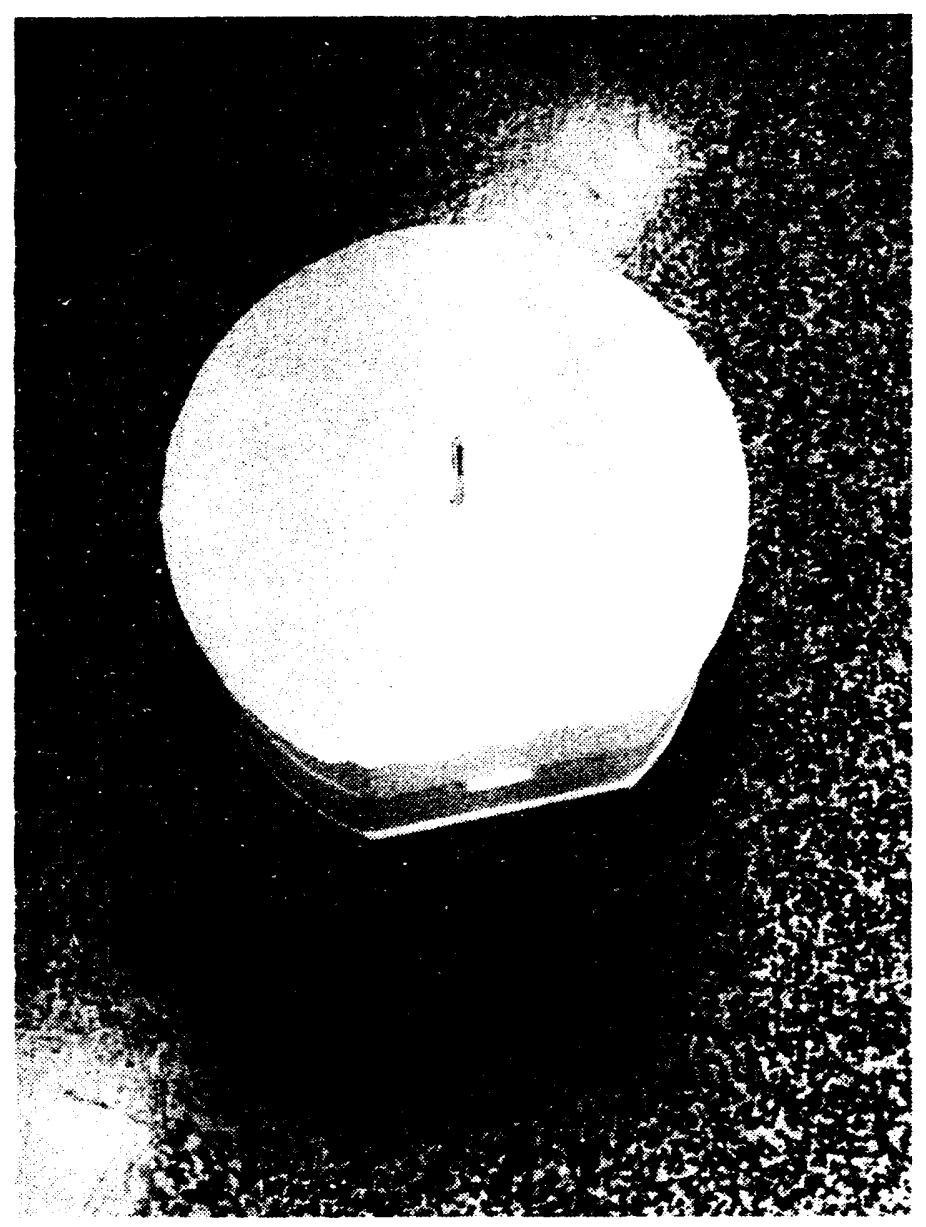

Figure 6 - Parchment paper placed over the shipping tray. 


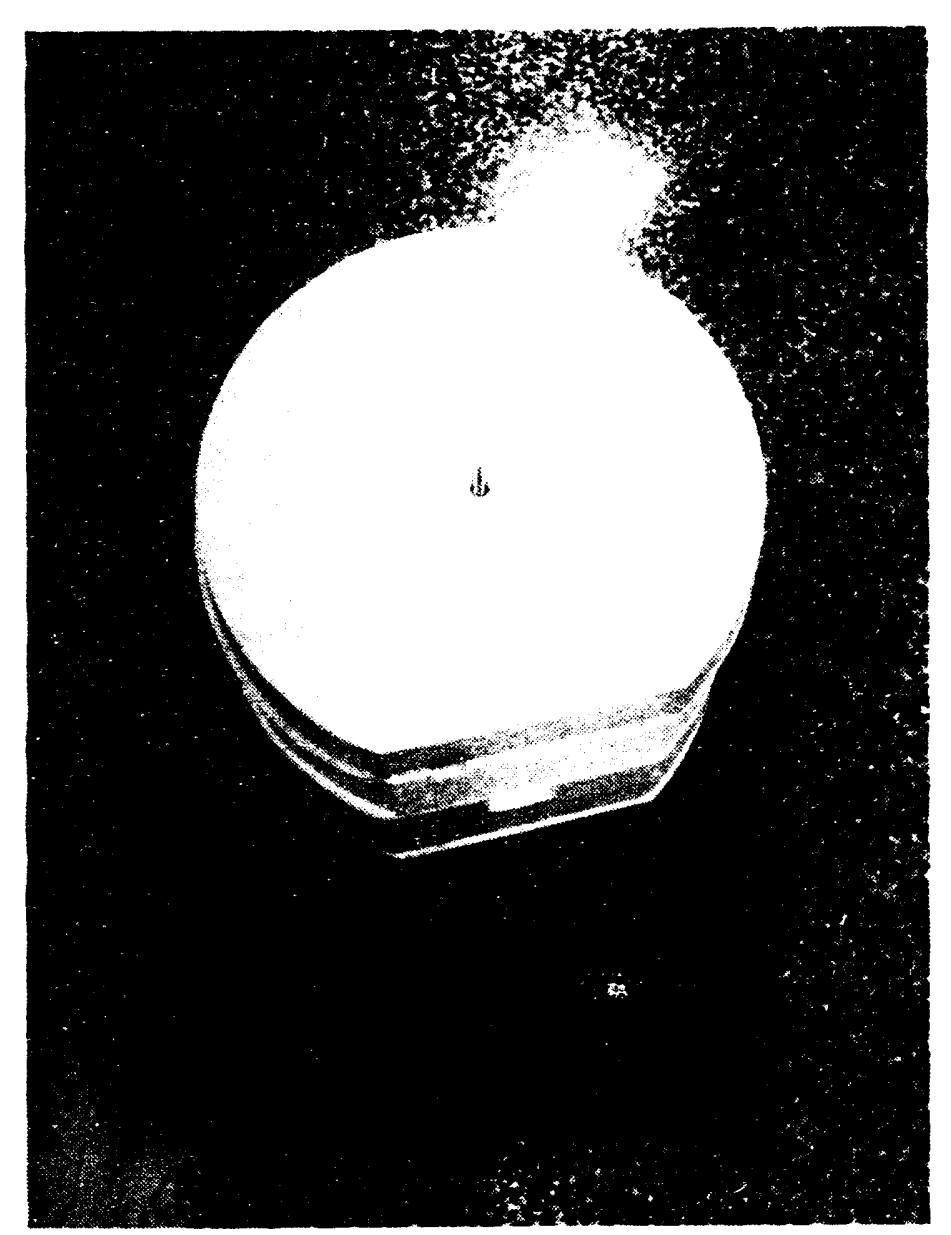

Figure 7 - Styrofoam spacer tray placed on top of the shipping tray.

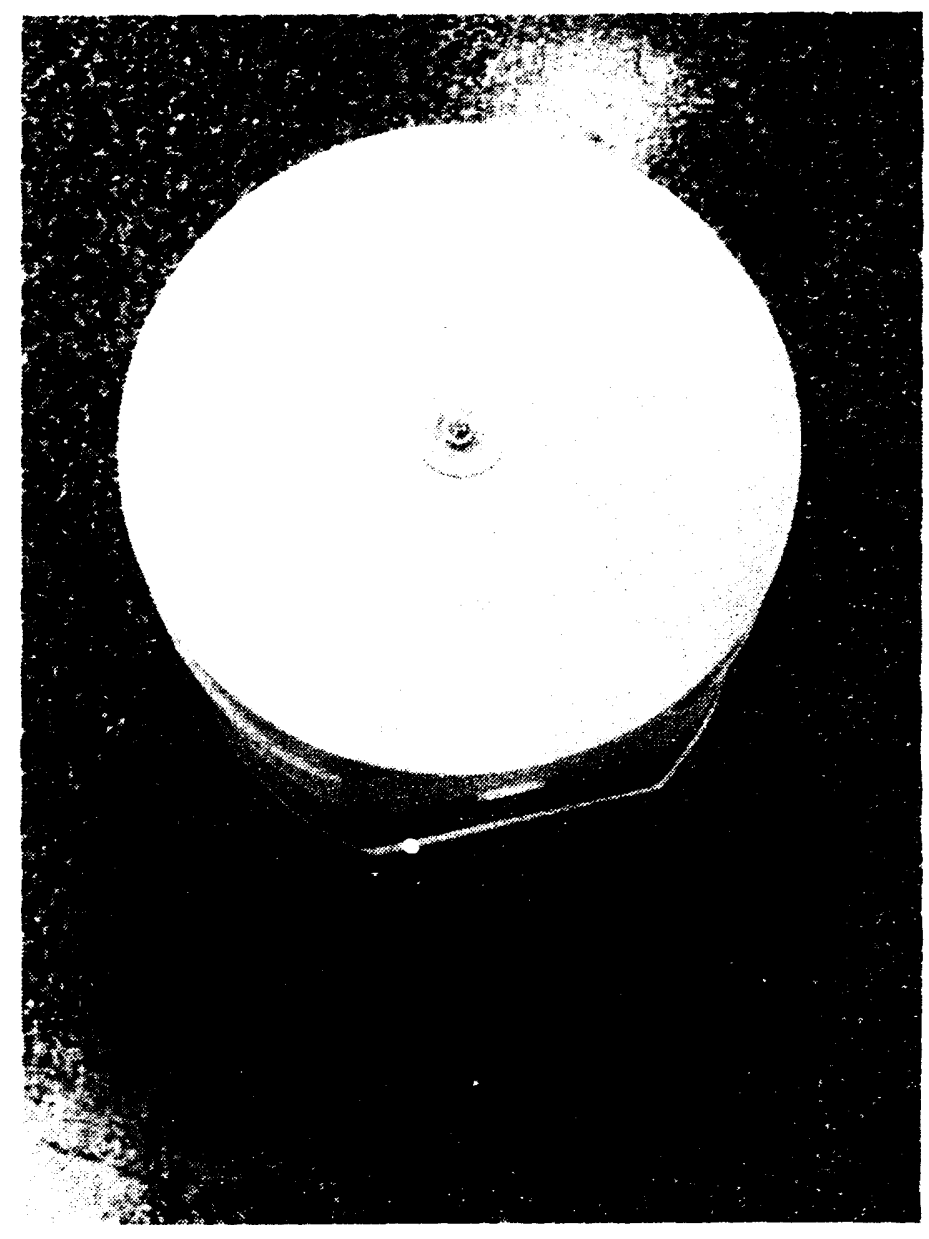

Figure 8 - Completed stack-up of inner package. Plywood disc placed on top of spacer tray. Stack held together by bolting after a lifting strap is placed over the wooden disc. 


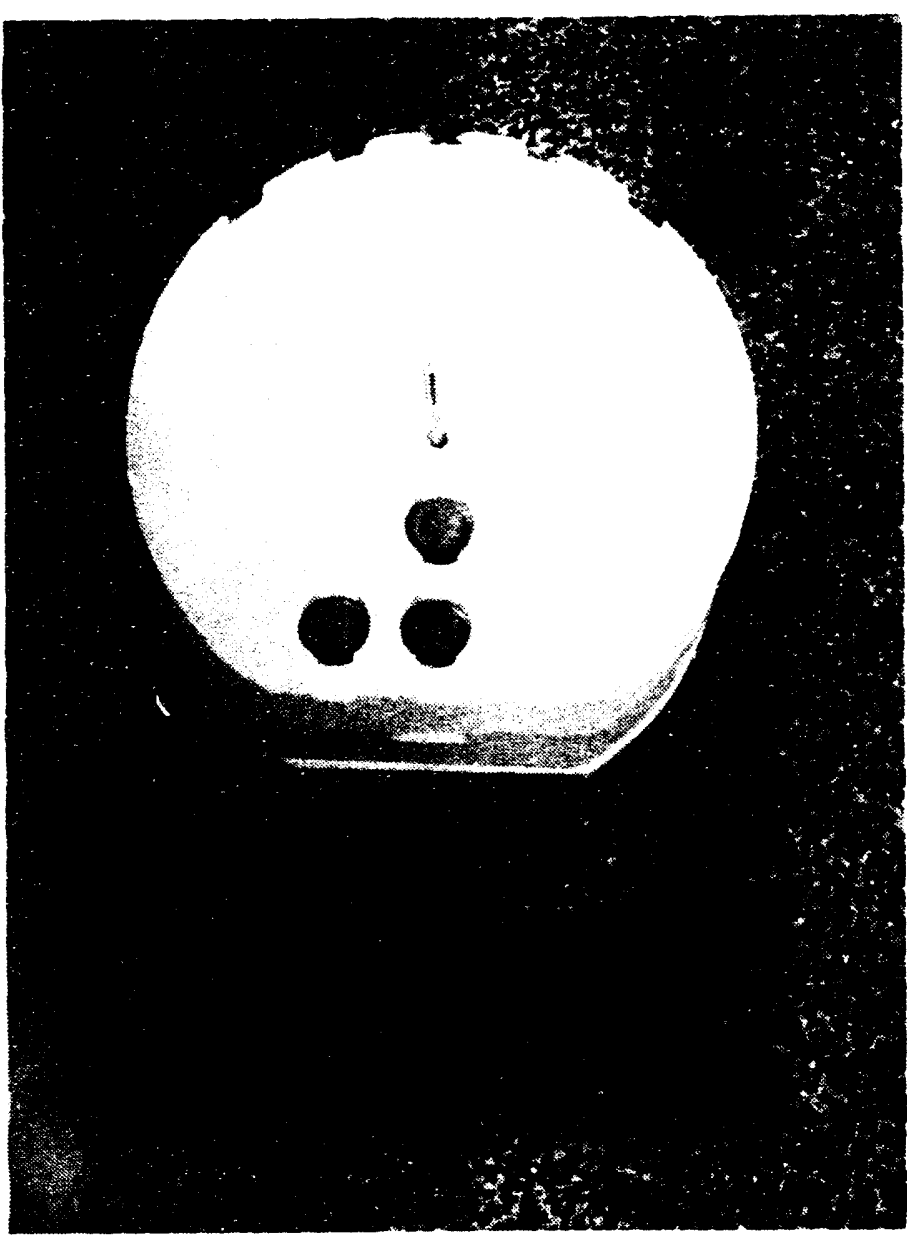

Figure 9 - Shipping tray with HVI assemblies for the test.

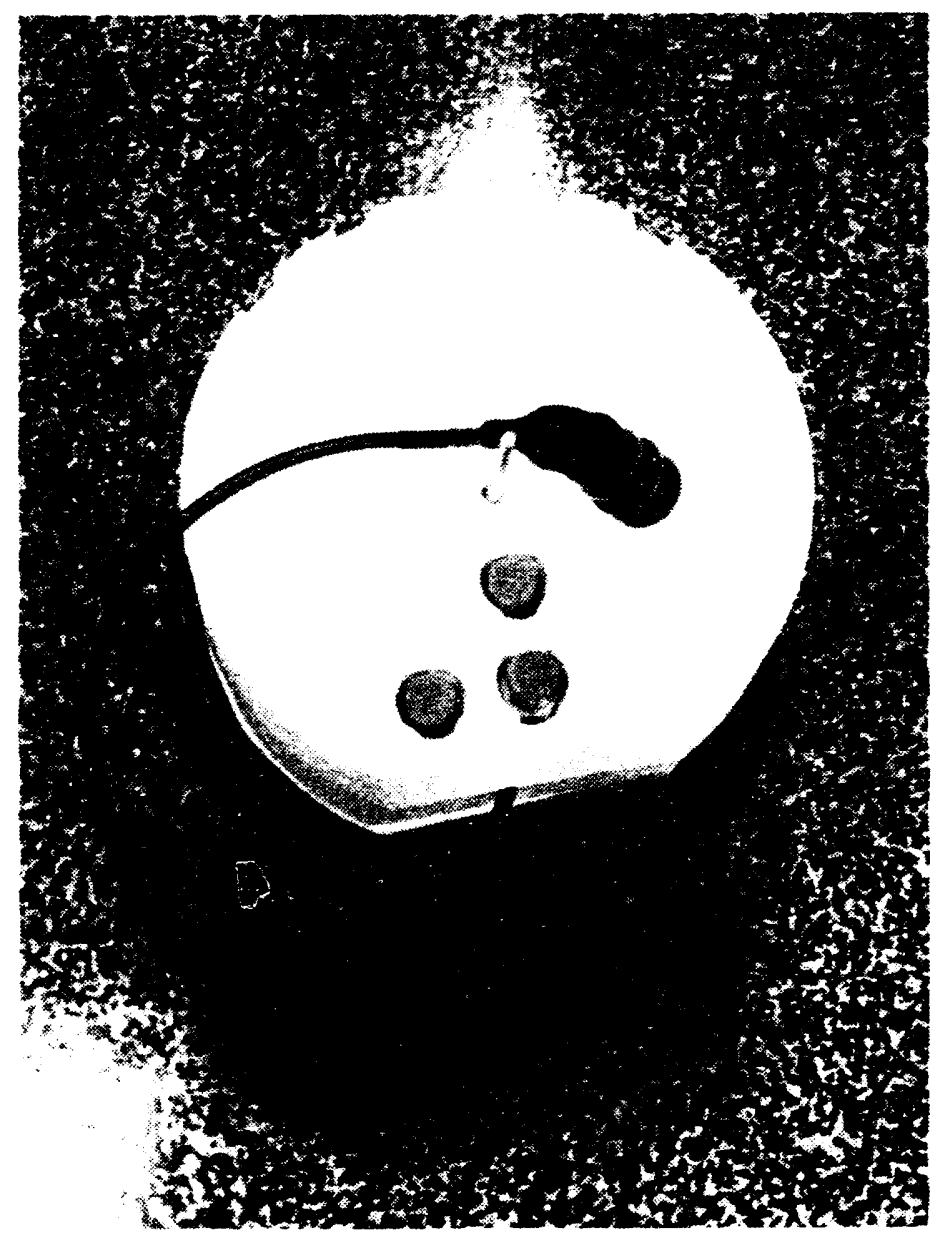

Figure 10 - Shipping tray with firing cable attached to HVI. 


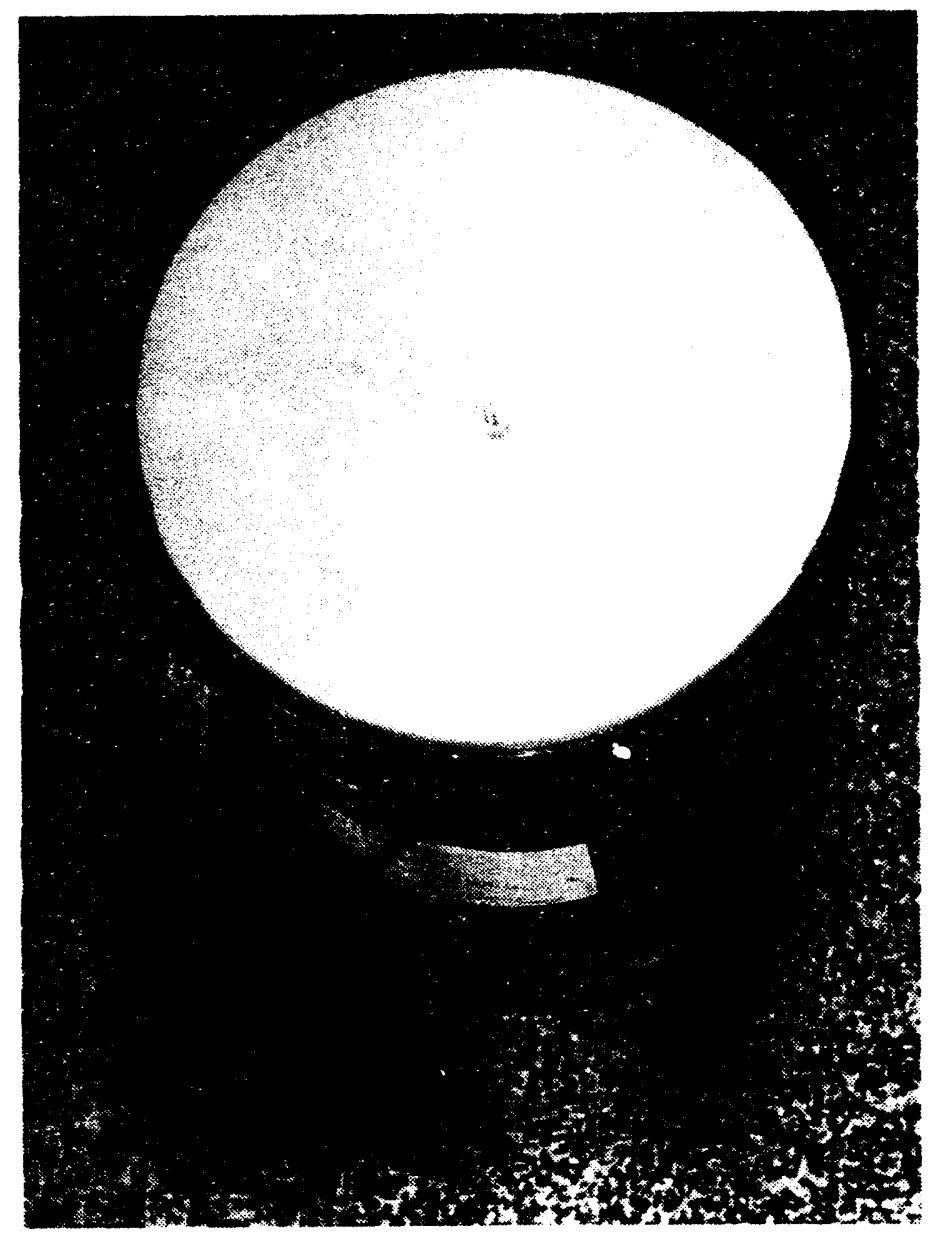

Figure 11 - Inner package placed inside outer metal drum.

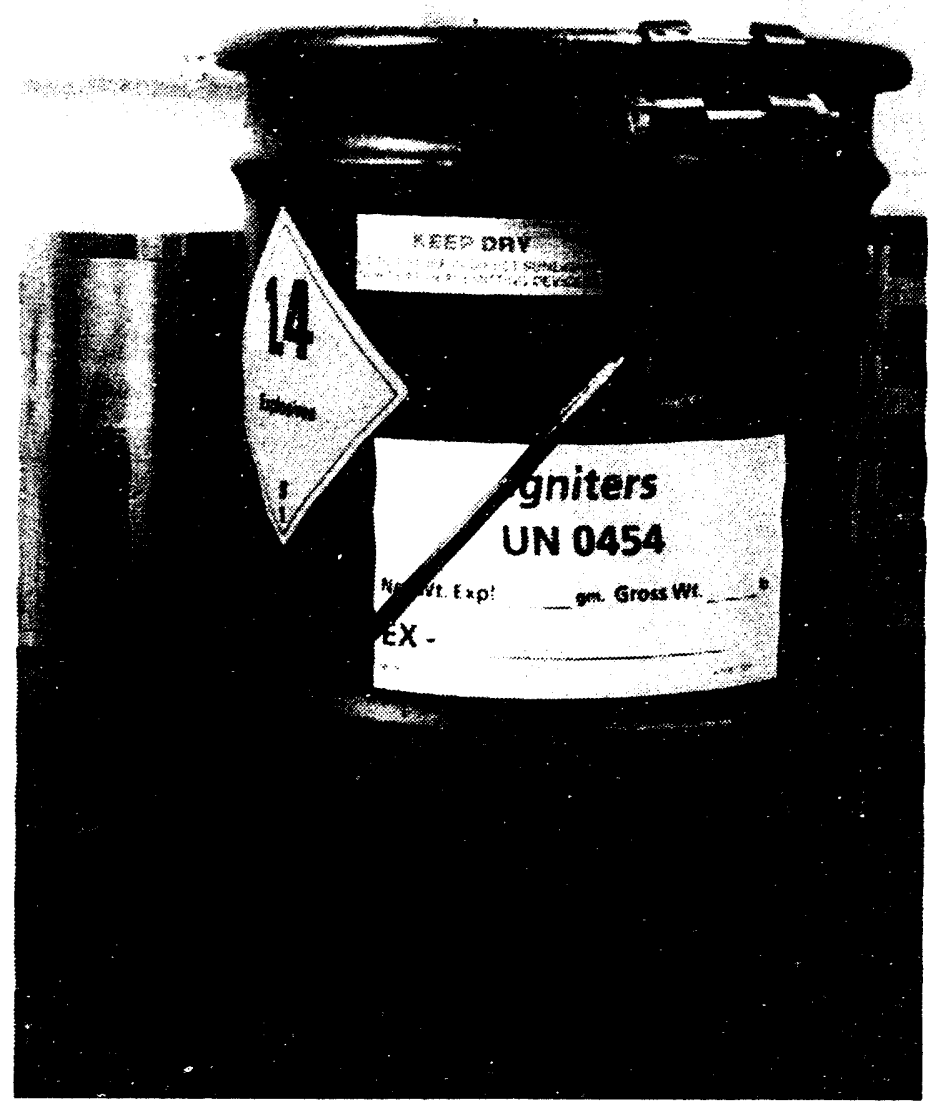

Figure 12 - Container ready for testing with lid in place and bolted. 


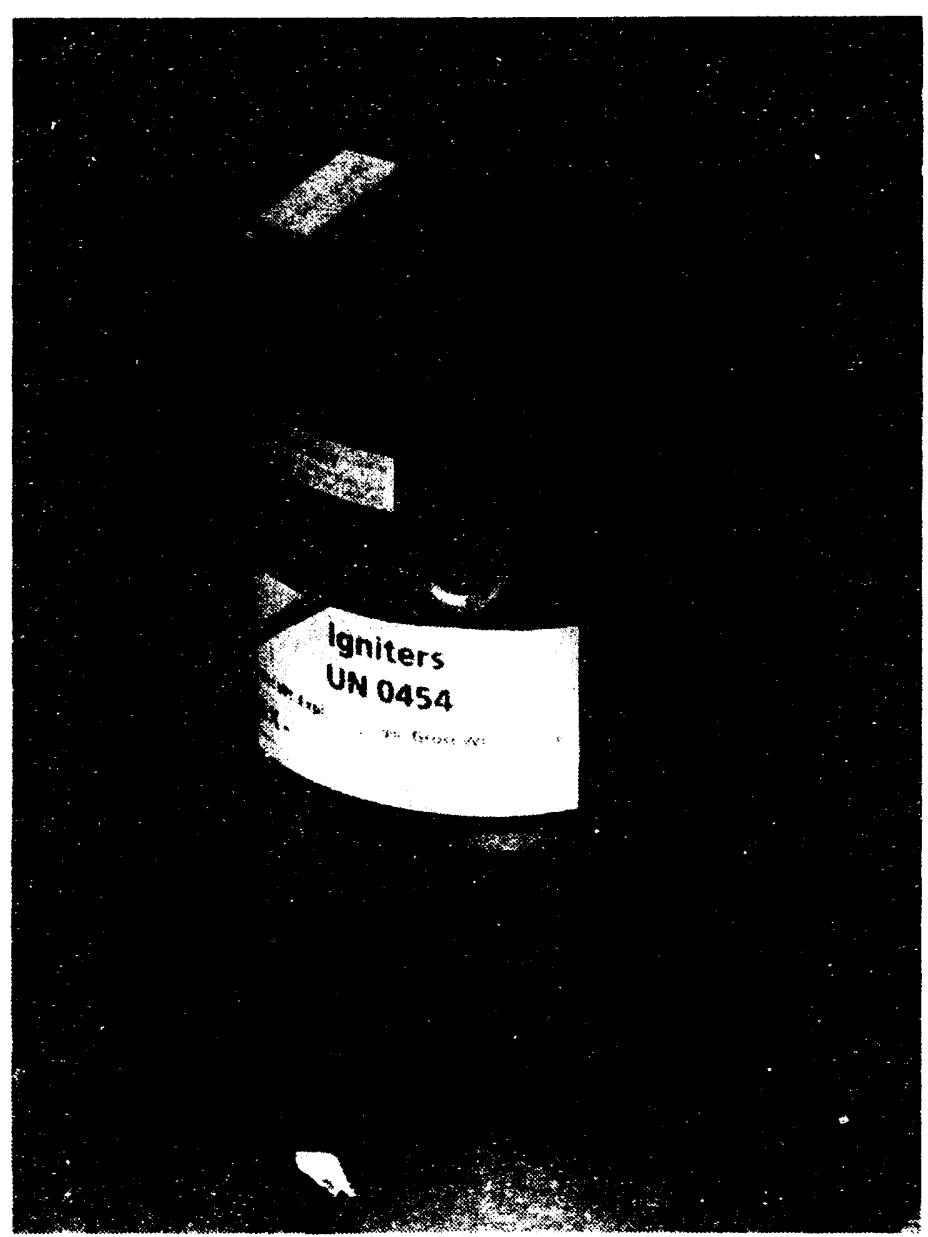

Figure 13 - Container after detonation of the HVI. No damage was done to the container.

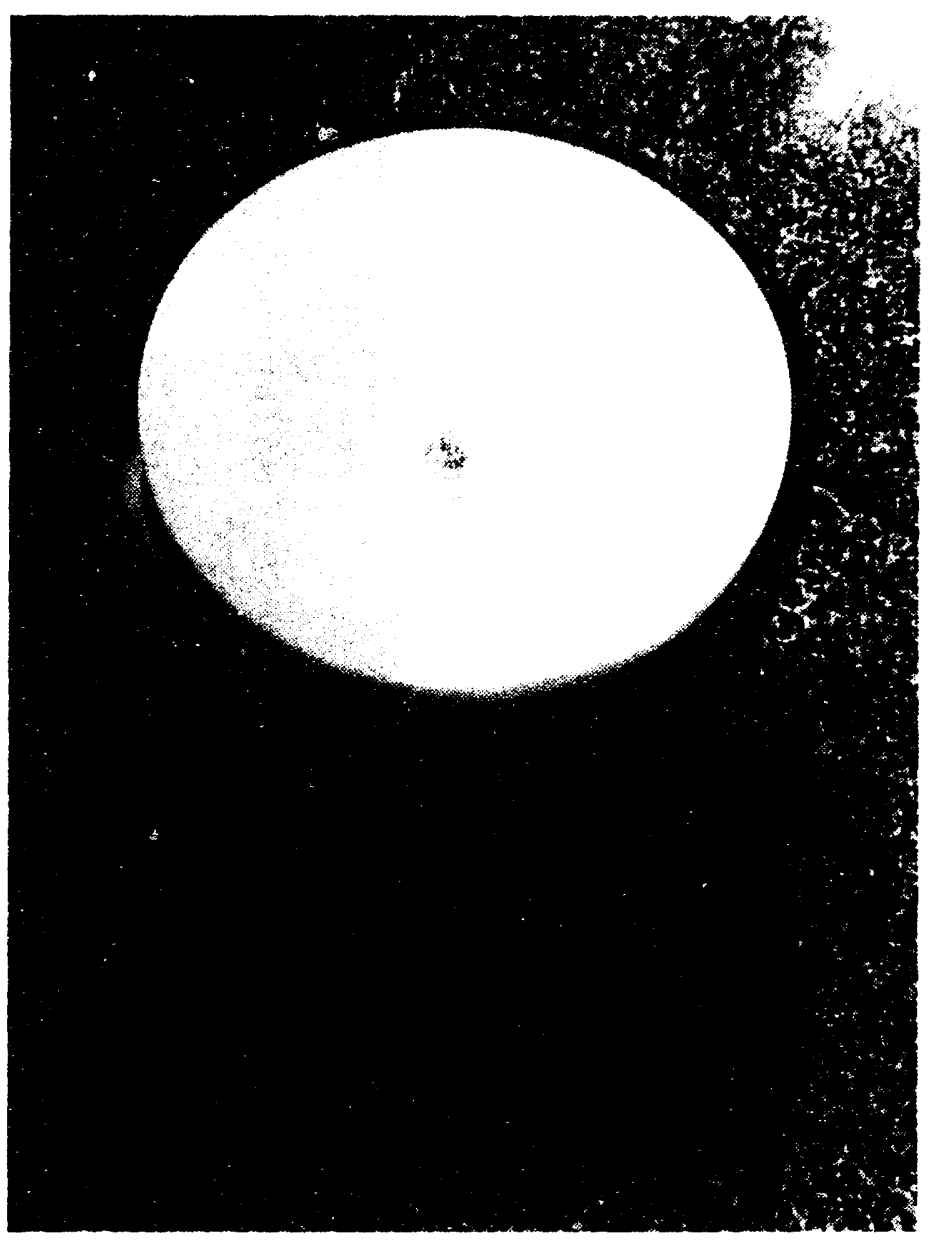

Figure 14 - Container with lid removed. No damage was observed. 


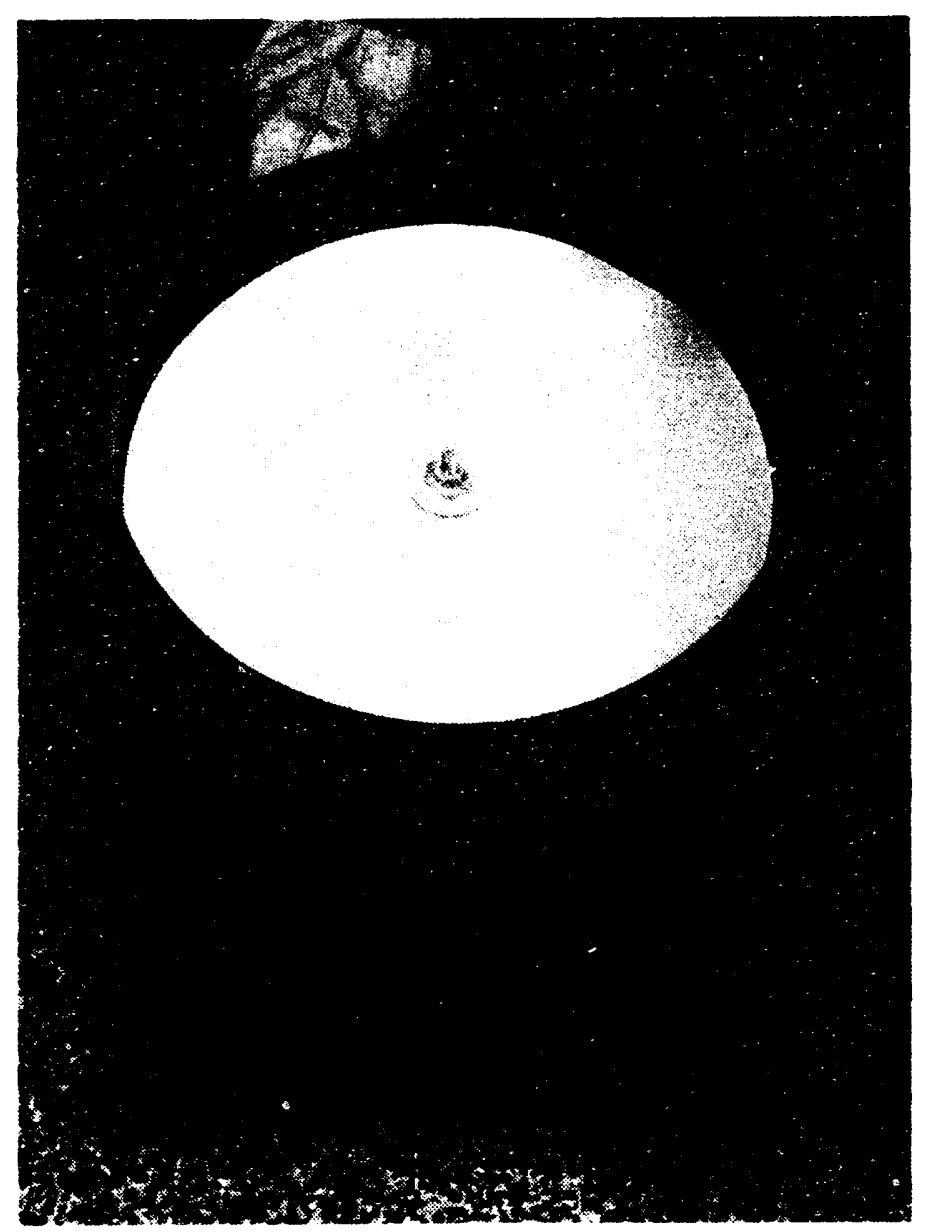

Figure 15 - Container with polyurethane ring removed. No damage observed.

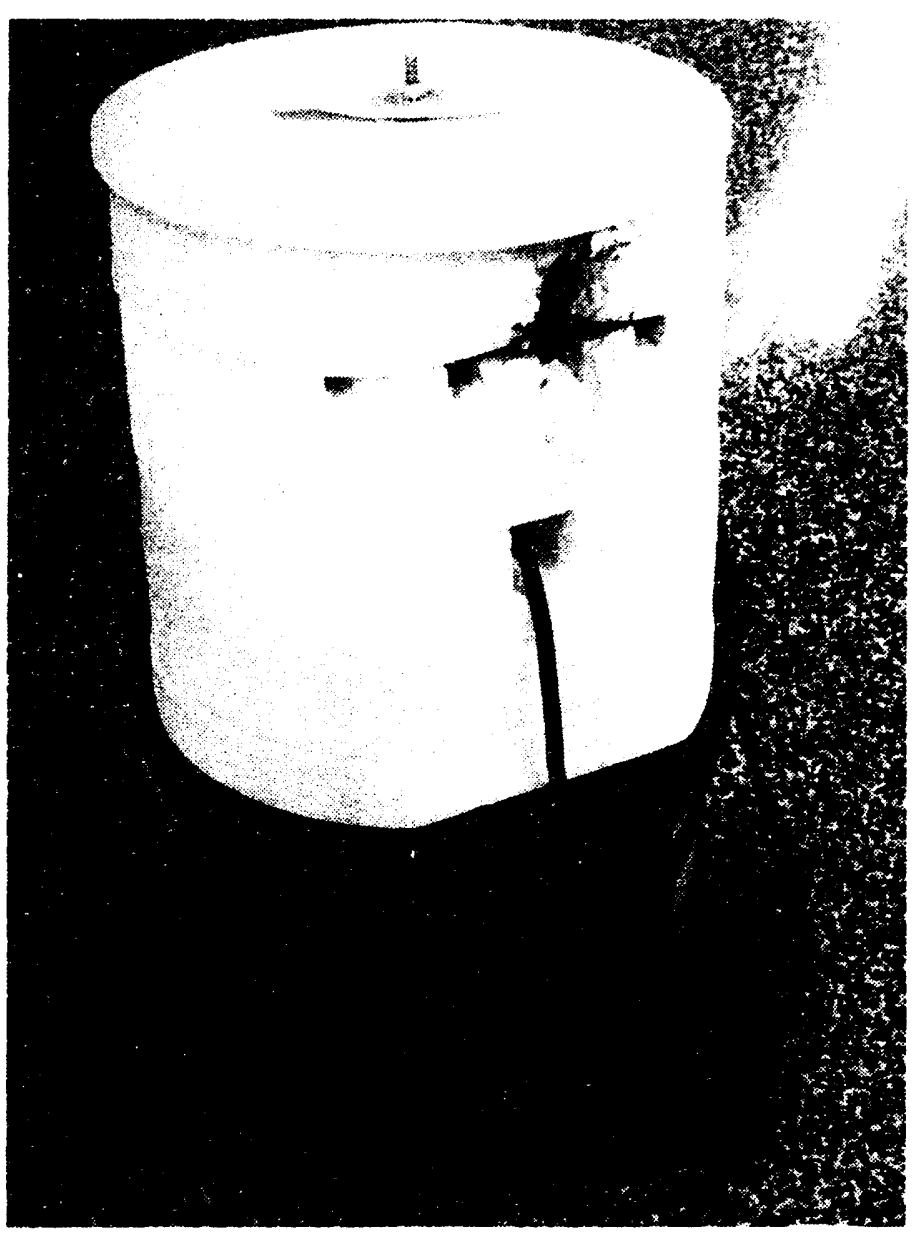

Figure 16 - Inner package removed from metal drum. Damage from detonation of HVI noted on side of inner package. 


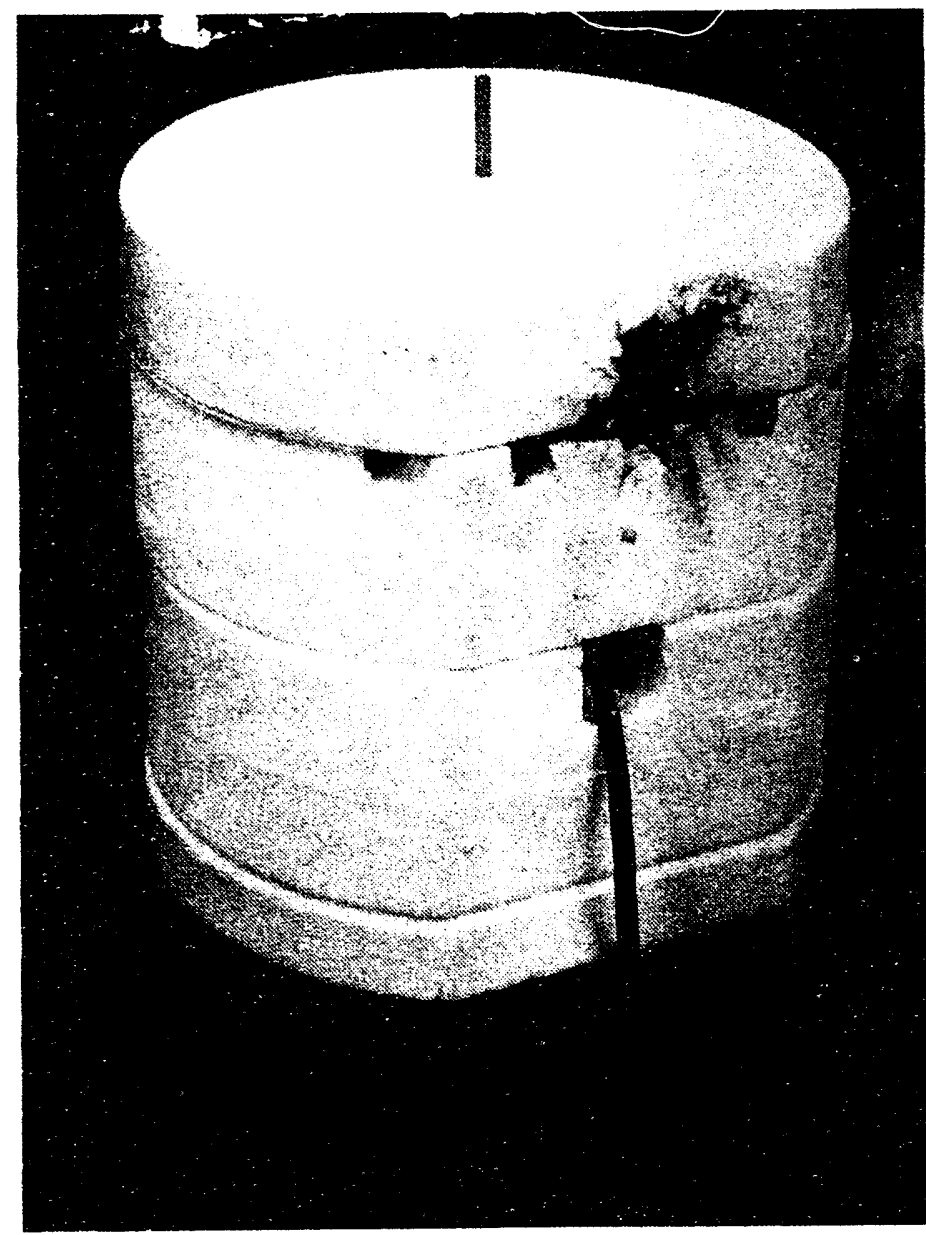

Figure 17 - Inner package with wooden disc removed.

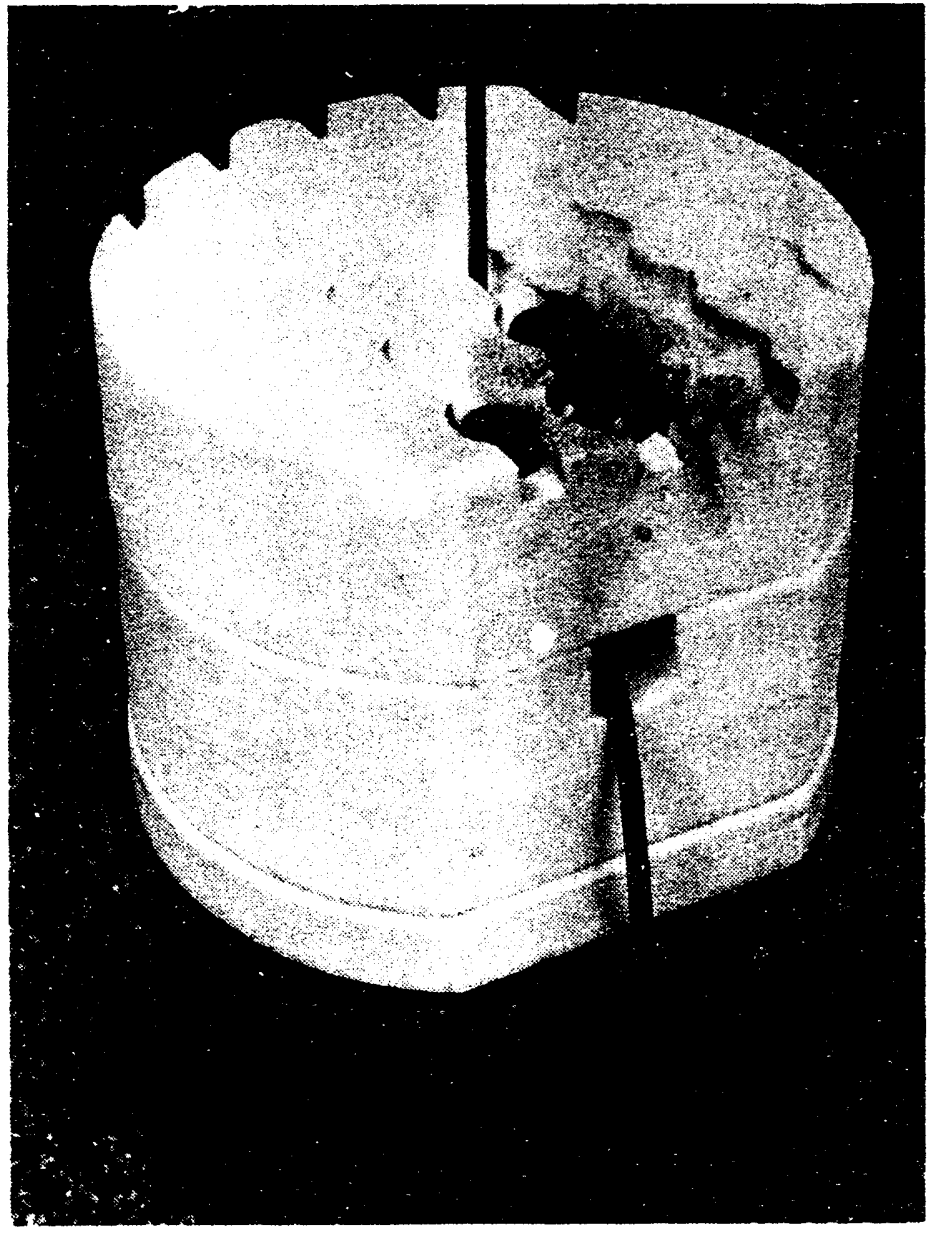

Figure 18 - Top spacer removed. Nonpropagation noted to two HVI assemblies next to HVI detonated. 


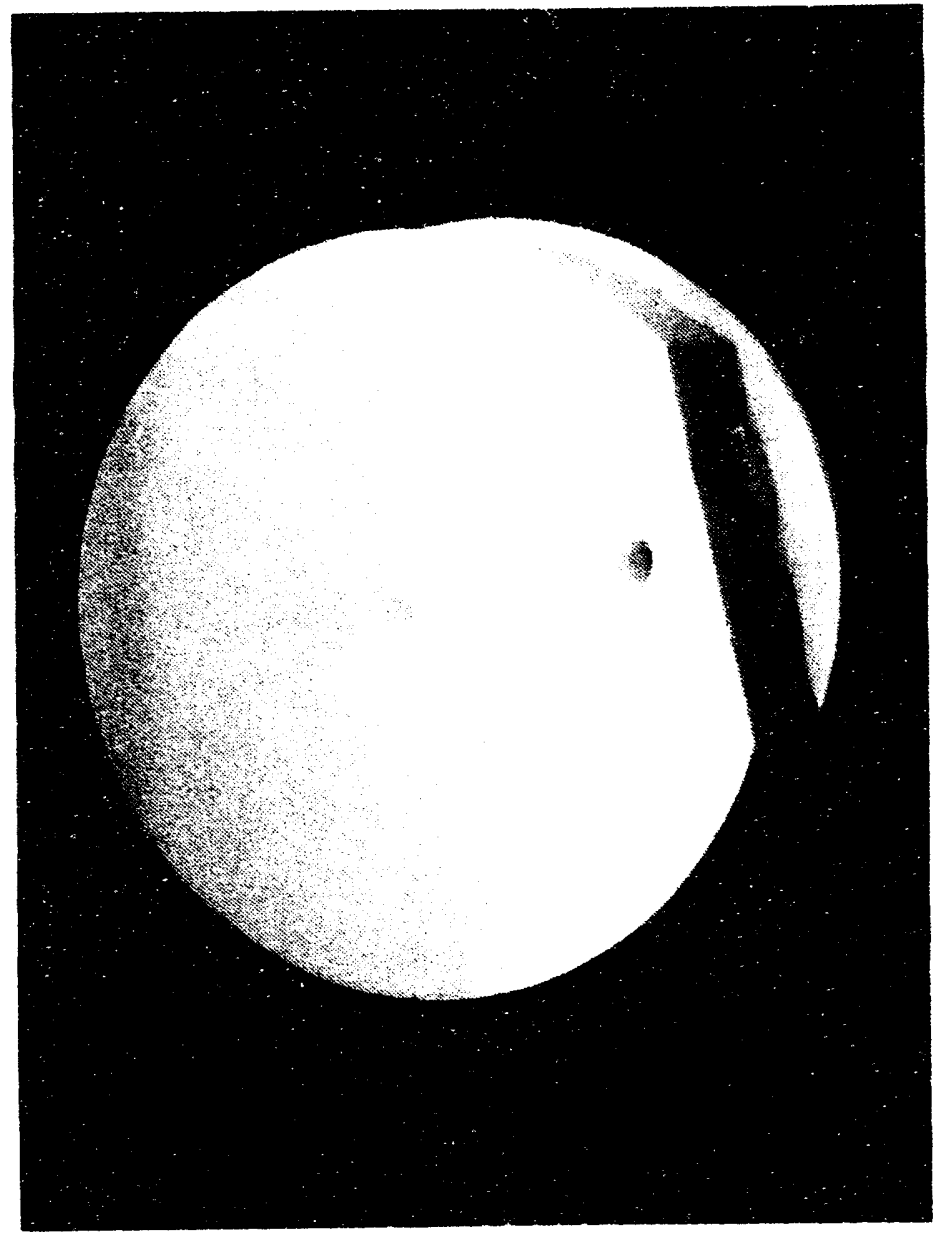

Figure 19 - Bottom of shipping tray with no damage noted.

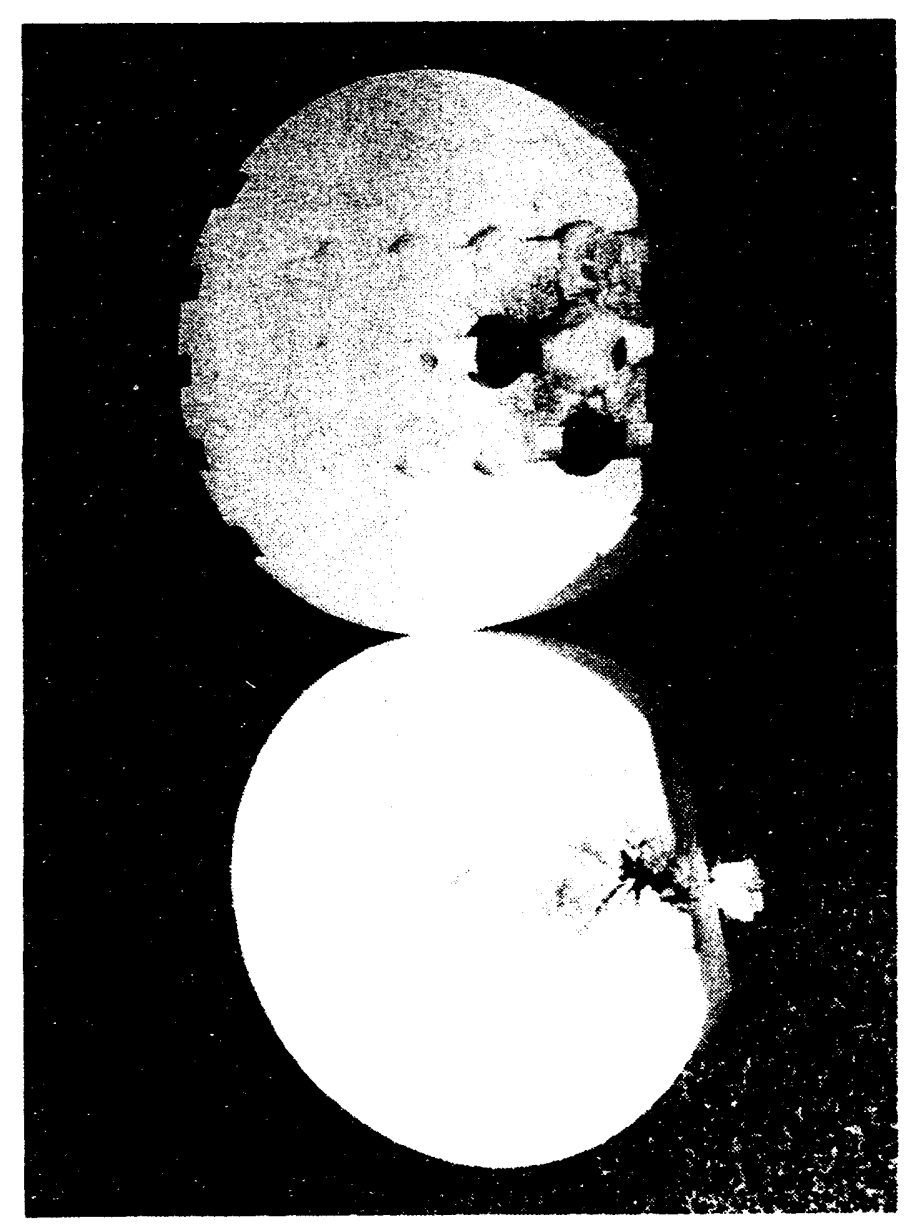

Figure 20 - Top of shipping tray with detonated HVI assembly removed. Bottom of top spacer tray showing damage. 


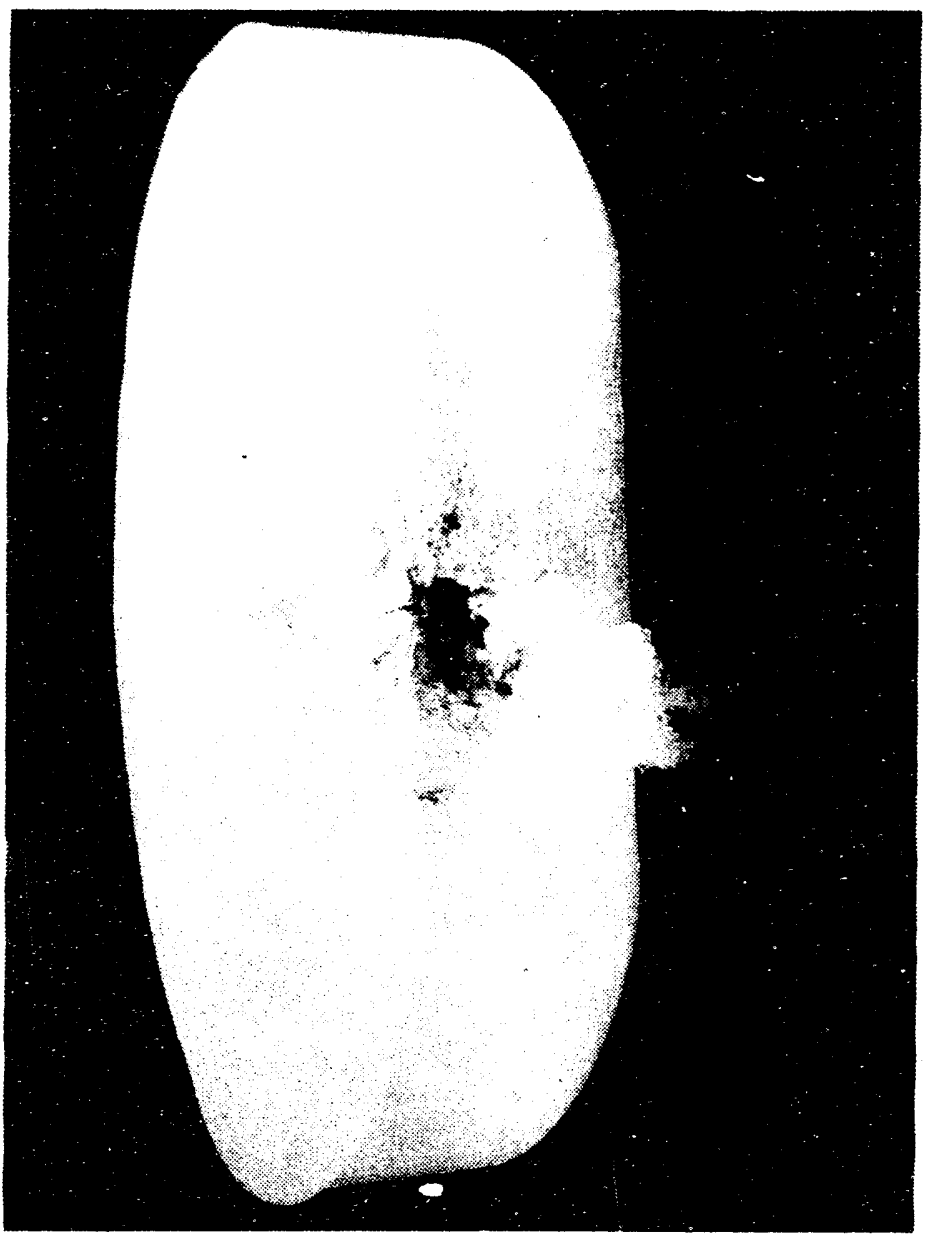

Figure 21 - Side of top spacer tray with damage noted. Part of top plastic cap and metal cover of HVI imbedded in tray.

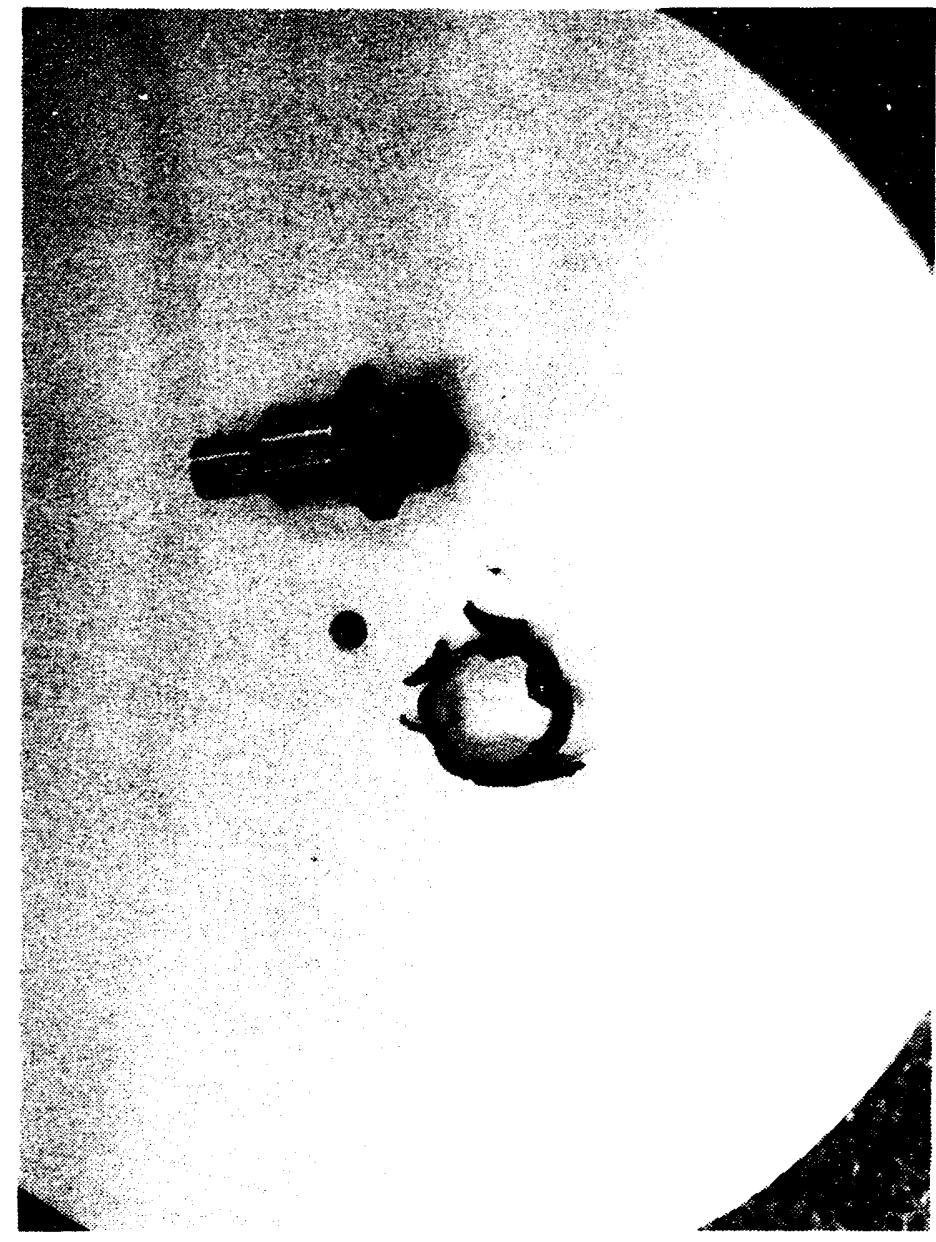

Figure 22 - Fired HVI with remains of the plastic cover. HVI housing remained intact. Scorching noted around threads. 


\section{Appendix A}

\section{Hazard Classification Documentation}


Revision No.:0

Date: $5 / 12 / 92$

SHIPPING APPROVAL CHECK IIST

ITEM NAME : HVI INITIATOR

CLASS IFICATION : IGNITERS

UN. NUMBER: 0325

HAZ . CLASS : $1,4 G$

DRAWING NUMBER

CERTIFICATION OF COMPLIANCE

ANALOGY STATEMENT

PACKAGING INDEX

PACKAGING SPECIFICATION

PROPAGATION TEST

MD-10052 REFERENCE

APPROI ED TRAY

NEW TRAY

SHIPPING APPROVAL NUMBER

SHIPPING PACKAGE

395710

00337

00337

NXB912442

SPA911442

HVI, $5 / 4 / 92$

NONE

3-1695

AYD911444

00337

AYD911444

CONTAINER WT.:5.0 gram

UNIT WT.:0.250 gms.

ITEMS:20 PER AYD770286 CONT.

DATE: $11-24-92$

DOT REFERENCE NO.: EX-9211171

DISTRIBUTION-APPROVAL

1. OSB/SPD/DOE-AL (3)

2. DAO-DOE

3. SR. MANFG. SPECIALIST

EG\&G-ML-7098 (12-91)

hzct $337 a$

Page 1.

18 
CERTIFICATION OF COMPLIANCE

FOR HAZARDOUS MATERIALS

ATTENTION MOUND EMPLOYEES SIGNING THIS CERTIFICATE: The laboratory, its directors, and/or you can be fined and/or imprisoned if this package does not comply with applicable Federal rules and regulations for packaging, marking, and labeling; thereby making this package safe for transportation.

TRADE NAME, DRAWING NUMBER:MC3748 INITIATOR (AY319851)

(ORIGINATORS IDENTIFICATION)

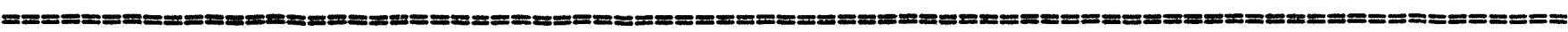
FILL IN ALL INFORMATION WITH REFERENCE TO ICAO REGULATIONS

\begin{tabular}{|c|c|c|c|}
\hline \multicolumn{2}{|l|}{$\begin{array}{l}\text { Proper Shipping Name (ICAO Table 2-14) } \\
\text { IGNITERS }\end{array}$} & $\begin{array}{l}\text { UN Number } \\
0325\end{array}$ & $\begin{array}{l}\text { Haz. Class. } \\
1.4 \mathrm{G}\end{array}$ \\
\hline $\begin{array}{l}\text { Classification (ICAO Table 2-14) } \\
1.4 \mathrm{G}\end{array}$ & $\begin{array}{l}\text { Required I } \\
\text { EXPLOSIVE }\end{array}$ & $\begin{array}{l}\text { Label (ICAO TabI } \\
21.4\end{array}$ & e 2-14) \\
\hline $\begin{array}{l}\text { Markings (ICAO Table 2-14) } \\
\text { IGNITERS, } 1.4 \mathrm{G}, \text { UN0325 }\end{array}$ & & $\begin{array}{l}\text { ICAO Packaging } \\
159\end{array}$ & Requirement \\
\hline
\end{tabular}
FILL IN ALL INFORMATION WITH REFERENCE TO DOT REGULATIONS

\begin{tabular}{l|l|l|l}
\hline $\begin{array}{l}\text { Proper Shipping Name (49 CFR 172.101) } \\
\text { IGNITERS }\end{array}$ & $\begin{array}{l}\text { UN Number } \\
0325\end{array}$ & $\begin{array}{c}\text { Haz. Class. } \\
1.4 G\end{array}$ \\
\hline $\begin{array}{l}\text { Classification (49 CFR 172.101) } \\
\text { l.4G }\end{array}$ & $\begin{array}{l}\text { Required Label (49 CFR 172.101) } \\
\text { EXPLOSIVE } 1.4 \mathrm{G}\end{array}$ \\
\hline $\begin{array}{l}\text { Markings (49 CFR 172.101) } \\
\text { IGNITERS, }=4 \mathrm{G}, \text { UN0325 }\end{array}$ & $\begin{array}{l}\text { 49CFR Packaging Requirement } \\
173.62, \text { E-141 }\end{array}$ \\
\hline
\end{tabular}

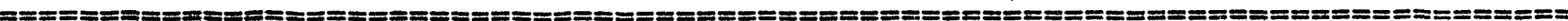

\begin{tabular}{c|c|c|c}
$\begin{array}{c}\text { Outside } \\
\text { Packaging }\end{array}$ & $\begin{array}{c}\text { No. units per } \\
\text { Package (max.) }\end{array}$ & Tray No. & $\begin{array}{c}\text { Units per Tray } \\
\text { (maximum) }\end{array}$ \\
\hline $\begin{array}{c}\text { AYD770286 } \\
\text { NXB911442 }\end{array}$ & 20 & AYD911444 & 20 \\
\hline
\end{tabular}

REMARKS: An analogy was done to the 1E26S DETONATOR classified as FUZES, DETONATING, 1.4S, UN0367 Classified by the DOT, EX-9204077, on 04/21/92. The shipping package as designed will contain all fragments and be nonpropagating. A propagation test was also done with no propagation or fragment excursion evident.

Page 2. 


\begin{tabular}{|c|c|}
\hline & $\begin{array}{l}\text { APPROVED } \\
\text { ITEM }\end{array}$ \\
\hline PAGE per MD-10052, Iss 3 & 12 \\
\hline TRADE NAME/ PART NO. & 15265 \\
\hline DRAWING NUMBER & 420513 \\
\hline PACKAGING INDEX & $N \times 4-4757$ \\
\hline TRAY NUMBER & $3-1695$ \\
\hline ITEMS per TRAY & 20 \\
\hline CONTAINER & AYD770286 \\
\hline TRAYS per CONTAINER & 5 \\
\hline EXPLOSIVE WT. per ITEM & 4.86 gram \\
\hline $\begin{array}{l}\text { EXPLOSIVE WT. per CONTAINE } \\
\text { DOT NUMBER }\end{array}$ & $\frac{486 \text { gram }}{\mathrm{EX}-9204077}$ \\
\hline
\end{tabular}

TYPE EXPLOSIVES
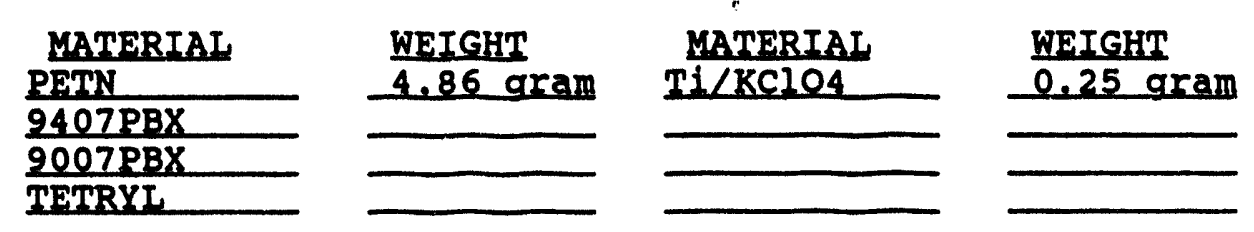

PROPAGATION TEST PEI MD-10052, ISSUE 3: SHIPPING APPROVAL NUMBER:00337

REMARKS: (Any difference between the approved item and the new item must be explained in sufficient detail for proper classification.) An analogy was done to the 1E26S Detonator classified as "FUZES, DETONATING, $1.4 \mathrm{~S}$, UN0367 by the DOT, EX-9204077. The shipping container for the HVI is similar to the shipping container for the 1E26S with fewer units per container. There is also significantly less explosives per HVI assembly. The HVI initiator was also propagation tested with no propagation and fragment excursion evident. It was recommended that the HVI Initiator be classified as "IGNITERS, 1.4G, UN0325" when packed per NXB911442 for shipping. 
SHIPPERS CERTIFICATION: This is to certify that the information above is correct and that if the above-named material is prepared in this manner it will be properly described by name and packed, marked, and be in proper condition for release to a carrier for transportation.

\begin{tabular}{l|l|l|c}
\hline $\begin{array}{l}\text { S. MANFG. SPEC. } \\
\text { ROBERT B. JONES }\end{array}$ & DATE & 3. OPERATIONAL SAFETY & DATE \\
\hline 2. PRODUCT ENGINEER & DATE & 4. TRAFFIC & DATE \\
\hline 5. GOGO AUTHORIZATION & DATE & 6. DOT REFERENCE NUMBER & DATE \\
\hline
\end{tabular}

Page 4. 


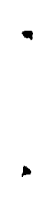




\section{Appendix B}

MSDS 
KSD8 No. :00237

C. of C. No.:000337

DATE : $5 / 11 / 92$

\section{MATERTAL BAPETY DATA BHEET}

EMERGENCY PHONE NO.:(513) $865-3400$ REVISION: 1

8ECTION I.

MANUFACTURER'S NAME AND FSCM (FEDERAL SUPPLY CODE FOR MANUFACTURER)

EGEG MOUND APPLIED TECHNOLOGIES, INC, (68)

ADDRESS (NUMBER, STREET, CITY, STATE, and ZIP CODE)

P.O. BOX 3000 YIAYISBURG, OH 45343-3000

CHEMICAL NAME: IGNITERS, $1.4 \mathrm{G}$, UN0325

TRADE NAME : HVI INITIATOR

CHEMICAL FAMILY: CONTAINS PYROTECHNICS

FORMULA : Titanium/Potassium Perchlorate (Ti/KClO4)

\begin{tabular}{|l|l|l|l|}
\hline FEDERAI STOCK NUMBER & GROSS WEIGHT (LBS) & OUTSIDE PACKAGE DIMENSIONS \\
P/N395710(NAVSEA6237177-001) & $30 \#$ & & \\
\hline
\end{tabular}

NATIONAL FIRE PROTECTION ASSOCIATION STD 704M SIGNAL

Flammability_2 Health_2 Reactivity_ 3 s secific Hazard PYROTECHNICS

BECTION II - EAZARDOUS INGREDIENTS

\begin{tabular}{|c|c|c|c|c|c|}
\hline $\begin{array}{c}\text { PAINTS, PRESERVATIVES } \\
\text { AND SOLVENTS } \\
\end{array}$ & 8 & $\begin{array}{l}\text { THRESHOLD } \\
\text { IIMIT VALUE }\end{array}$ & $\begin{array}{l}\text { ALLOYS AND METALLIC } \\
\text { COATINGS }\end{array}$ & 8 & $\begin{array}{l}\text { THRESHOLD } \\
\text { IIMIT VALUE }\end{array}$ \\
\hline $\begin{array}{l}\text { PIGMENTS } \\
\text { CATALYST } \\
\text { VEHICLE } \\
\text { SOLVENTS } \\
\text { ADDITIVES } \\
\text { OTHERS }\end{array}$ & $\begin{array}{l}N / A \\
N / A \\
N / A \\
N / A \\
N / A \\
N / A\end{array}$ & & $\begin{array}{l}\text { BASE METAL } \\
\text { ALLOYS } \\
\text { METALIC COATINGS } \\
\text { FILLER METAL, FLUX } \\
\text { OTHERS }\end{array}$ & $\begin{array}{l}\text { N/A } \\
\text { N/A } \\
\text { N/A } \\
N / A \\
\text { N/A }\end{array}$ & \\
\hline
\end{tabular}

HAZARDOUS MIXTURES OF OTHER LIQUIDS, SOLIDS, OR GASES

The HVI Initiator contains 0.25 gram of Titanium/Potassium Perchlorate (Ti/KClO4) in a sealed assembly.

THE UNO CLASSIFICATION NO.: UN0325,

HAZARD CLASSIFICATION: CIASS 1 DIVISION 4.

STORAGE COMPATIBILITY GROUP: $G_{\text {. }}$

DOD FORY 1813 (June 71)

(ONB NO. 45-RO338, MAY 31, 1976)

Page 1 
BECTION III - PEYSICAL DATA

\begin{tabular}{l|l|l|l|} 
BOILING POINT (deg F) & N/A & SPEC. GRAVITY (H2O=1) & N/A \\
VAPOR PRESS. (mm Hg) & N/A & VOIATILES BY VOL. $(r)$ & N/A \\
VAPOR DENS. (AIr=1) & N/A & EVAPORATION RATE & N/A \\
SOLUBILITY IN WATER & N/A & & N/A \\
APPEARANCE and ODOR: & N/A &
\end{tabular}

8ECTION IV - PIRE and EXPIOBION HAZARD DATA

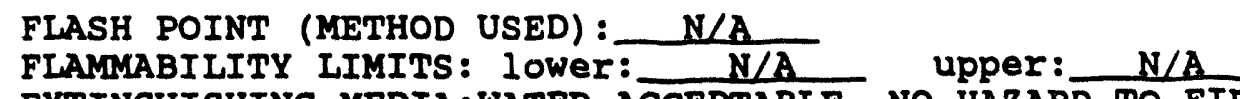

EXTINGUISHING MEDIA: WATER ACCEPTABLE NO HAZARD TO FIREMEN IF CONTAINERS

ARE INTACT.

SPECIAL FIRE FIGHTING PROCEDURES: PRESENCE OF SEALED CONTAINERS DOES NOT

ADD SIGNIFICANTIY TO HAZARD

UNUSUAL FIRE and EXPLOSION HAZARDS: INDIVIDUAL ITEMS OUTSIDE OF CONTAINERS

MAY DETONATE IF INVOLVED IN FIRE.

TOXIC GASES MAY BE GENERATED EROM PACKAGING MATERIALS BY FIRE.

SECYION $\nabla$ - EEALTH RARARD DATA

THRESHOLD LIMIT VALUE:NONE, IF NO CONTACT IS NADE WITH PYROTECHNIC MATERIAIS. EFFECTS OF OVER EXPOSURE: NONE, IF NO CONTACT IS MADE WITH PYROTECHNIC MAT'LS, EMERGENCY and FIRST AID PROCEDURES:STANDARD FIRST AID PROCEDURES FOR INJURIES *SEE TOXICITY DATA FOR TITANIUM SUBHYDRIDE/POTASSIUM PERCHLORATE (TI/KC104).

\section{BECTION VI - REACTIVITY DATA}

STABILITY: STABLE: $X$ UNSTABIE:

CONDITIONS TO AVOID: KEEP AWAY FROM FIRE AND FIECTRICAL POWER SOURCE

DO NOT CRUSH.

INCOMPATIBILITY : NONE NORMALLY

HAZARDOUS DECOMPOSITION PRODUCTS:BURNING PACKAGING MATERIALS COULD PRODUCE

TOXIC PRODUCTS.

HAZARDOUS POLYMERIZATION: $\mathrm{N} / A \quad$ MAY OCCUR: $N / A$

CONDITIONS TO AVOID: KEEP AWAY FROM FIRE

BECTION VII - BPILL OI LEAK PROCEDURES

STEPS TO BE TAKEN IN CASE MATERIAL IS RELEASED OR SPILIED: IF IOOSE POWDER IS PRESENT, CAREFUILY WIPE UP WITH A DAMP CLOTH. IF ITEYS ARE DROPPED, CAREEUT,Y PICK UP AND PIACE IN A STORAGE TRAY AND MARK, AVOID ANY IMPACT, HEAT, OR FIECTYROSTATIC DIFFERENTIAL, SHOULD BE GROUNDED,

WASTE DISPOSAL METHOD: PYROTECHNIC MATERIALS SHOULD BE SEGREGATED FROM OTHER

YATERTATS, APPROVFD YETHODS SHOUTL BE USED TO DESTROY DAYAGED ITEMS.

PHRSONNEI, SHOUTD BE GROUNDFD, PROPFR BOUTPYIFNT SHALI, BE USED.

Page 2 
RESPIRATORY PROTECTION (SPECIFY TYPE) : NONE - EXCEPT FOR FIGHTING FIRE

VENTILATION REQUIRED: STANDARD TYPE: IOCAL EXHAUST

PROTECTIVE GLOVES : NONE - IF USED SHOUTD BE CONDUCTIVE

EYE PROTECTION: STANDARD SAFETY GLASSES AS A MINIMUM

OTHER PROTECTIVE EQUIPMENT: STATIC GROUNDING DEVICES FOR PERSONNEL REOUIRED

DURING CIEANUP OF DAYAGED ITEYS. AISO REOUIRED FOR HANDLING ITEYS ANY TIME.

\section{ECTION IX - BPECIAI PRECAOTIONB}

PRECAUTIONS TO BE TAKEN IN HANDLING AND STORING:STORE INTACT ITEMS IN SHIPPING CONTAINGRS. ITHYYS ARE THEN CIASSIFIED AS SGC 1,4 FOR STORAGE. OTHER PRECAUTIONS : CRUSHED OR DAYAGED ITEYS SHALT BE STORED SEPARATELY FROM OTHER EXPIOSIVES AND MATERIAIS.

\section{SECYION $X$ - TRANSPORTATION DATA}

PROPER SHIPPING NAME (DOT): IGNITERS

DOT CLASSIFICATION: $1.4 \mathrm{G}$

DOT MARKING: IGNTTERS, 1.4G, UNO325

DOT REFERENCE: 49 CFR 172.101

PROPER SHIPPING NANE (ICAO): IGNITERS, $1.4 \mathrm{G}$

ICAO CIASSIFICATION: 1.46 UN NUMBER:0325 ICAO LABEL: 1.4G

ICAO PACKAGE NULBER: $\frac{159}{159}$ ICAO REFERENCE: ICAO Table 2-14

EMERGENCY ACCIDENT PRECAUTIONS and PROCEDURES:NOTIFY SHIPPER: SEE SECTION VII

ABOVE.

PRECAUTIONS TO BE TAKEN IN TRANSPORTATION:DO NOT CRUSH CONTAINERS: HANDLE

CAREFUTIY: KAEP AWAY FROY FIRE. 


\section{Distribution}

EXTERNAL

OSTI, UC-741 (35)

L. C. Allen, Sandia Natinal Laboratories, Albuquerque

J. Biggers, DOE/ALO

M. Dixon, PMOSSP Navy

J. G. Harlan, Sandia National Laboratories, Albuquerque

J. Janton, Westinghouse

L. Kirkman, DOE/DAO

I. H. Schmitz, DOE/DAO

M. Soto, SP2211 Navy

\section{INTERNAL}

J. J. Bayne

T. M. Bruggeman

D. A. Buckner

R. D. Burnett

A. F. Ciramella

J. L. Clark

J. D. Cogan (5)

E. E. Egleston

N. D. Frohlich

E. E. Tibbitts

R. L. Wood

Library (5)

Publications 

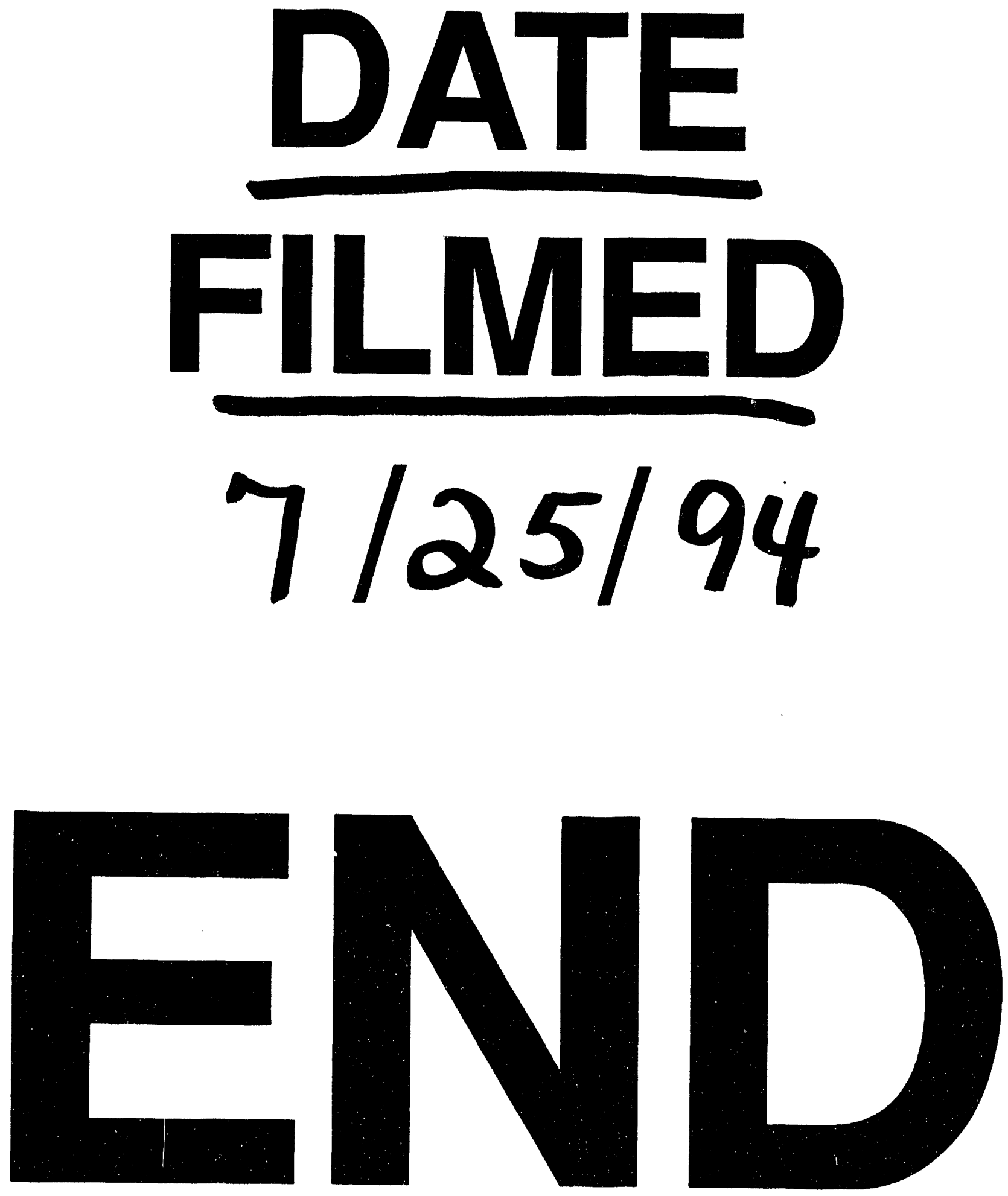
